\title{
Role of Endogenous Regulators of Hem- And Lymphangiogenesis in Corneal Transplantation
}

\author{
Thomas Clahsen ${ }^{1,2, *}$, Christian Büttner ${ }^{3}$, Niloofar Hatami ${ }^{1}$, André Reis ${ }^{3}[0$ \\ and Claus Cursiefen ${ }^{1,2}$ \\ 1 Department of Ophthalmology, University of Cologne, \\ Faculty of Medicine and University Hospital Cologne, 50937 Cologne, Germany; \\ niloofar.hatami@uk-koeln.de (N.H.); claus.cursiefen@uk-koeln.de (C.C.) \\ 2 Center for Molecular Medicine (CMMC), University of Cologne, 50937 Cologne, Germany \\ 3 Institute of Human Genetics, University Hospital Erlangen, \\ Friedrich-Alexander-Universität Erlangen-Nürnberg, 91054 Erlangen, Germany; \\ Christian.Buettner@uk-erlangen.de (C.B.); andre.reis@uk-erlangen.de (A.R.) \\ * Correspondence: Thomas.Clahsen@uk-koeln.de; Tel.: +49-221-478-32785
}

Received: 27 December 2019; Accepted: 7 February 2020; Published: 9 February 2020

\begin{abstract}
Under normal conditions, the cornea, being the transparent "windscreen" of the eye, is free of both blood and lymphatic vessels. However, various diseases of the eye, like infections, can interfere with the balance between promoting and inhibiting factors, which leads to ingrowth of blood and lymphatic vessels. The newly formed lymphatic vessels increase the risk of graft rejection after subsequent corneal transplantation. Corneal transplantation is one of the most commonly performed transplantations worldwide, with more than 40,000 surgeries per year in Europe. To date, various anti-hem- and anti-lymphangiogenic treatment strategies have been developed specifically for the corneal vascular endothelial growth factor (VEGF) pathway. Currently, however, no treatment strategies are clinically available to specifically modulate lymphangiogenesis. In this review, we will give an overview about endogenous regulators of hem- and lymphangiogenesis and discuss potential new strategies for targeting pathological lymphangiogenesis. Furthermore, we will review recently identified modulators and demonstrate that the cornea is a suitable model for the identification of novel endogenous modulators of lymphangiogenesis. The identification of novel modulators of lymphangiogenesis and a better understanding of the signaling pathways involved will contribute to the development of new therapeutic targets for the treatment of pathological lymphangiogenesis. This, in turn, will improve graft rejection, not only for the cornea.
\end{abstract}

Keywords: cornea transplantation; graft rejection; lymphangiogenesis; modulators of lymphangiogenesis

\section{Introduction}

The cornea is a well-established model to analyze the mechanism underlying (lymph)angiogenesis. In its normal condition, the cornea is devoid of blood and lymphatic vessels [1]. The blood and lymph vessels coming from the conjunctiva terminate in the limbal region, the border between the vascularized conjunctiva and avascular cornea. A further advantage of the cornea is its transparency and exposed position, enabling easy visualization and imaging of pathological corneal neovascularization. The precise balance of pro- and anti-(lymph)angiogenic factors play a very important role in maintaining this avascularity and transparency. A number of pathologic insults, such as inflammation, infection, trauma, and chemical burns [2,3] lead to an imbalance between pro- and anti-(lymph)angiogenic factors. This imbalance can cause the ingrowth of blood and lymphatic vessels into the cornea which not only results in reduced vision but also increases the risk for immune reactions after 
necessary cornea transplantation. The corneal immune privilege is important for the success of corneal transplantation and closely relates to the avascular nature of the cornea. The grafts, transplanted into an avascular corneal recipient bed (normal-risk keratoplasty), show a five-year survival rate of over $90 \%$. In contrast, grafts, implanted into pathologically prevascularized murine corneal recipient beds (high-risk keratoplasty) (Figure 1), are rejected in more than $50 \%$ of transplantations despite immunosuppressive therapy [4,5]. Therefore, treatments prior to transplantation that reduce the blood and lymphatic vessel load in inflammation would be a great benefit.

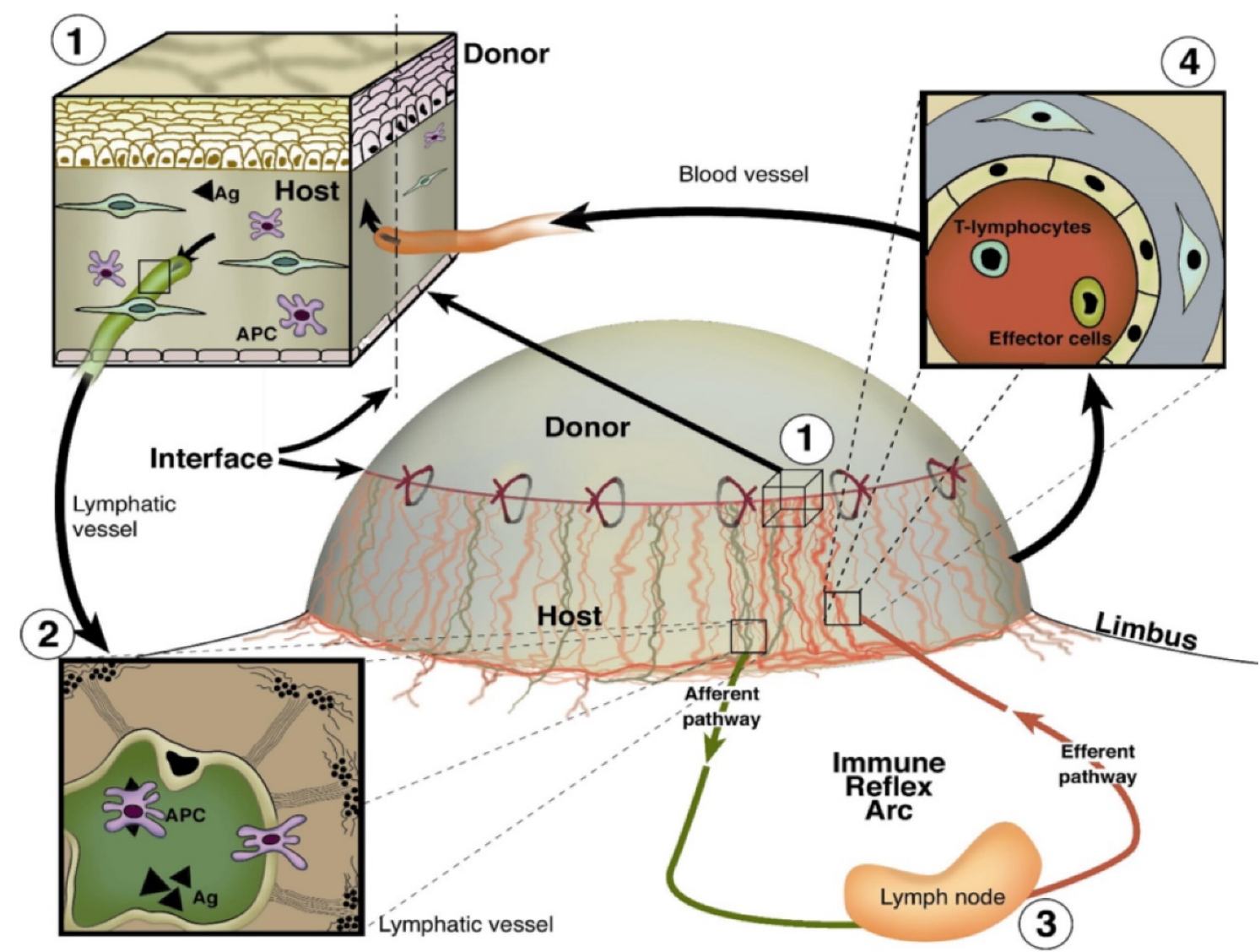

Figure 1. Important role of blood and lymphatic vessels in the high-risk corneal host bed as exit and entry routes of the immune reflex arc leading to immunologic graft rejection. (1) Magnification of the host-graft interface where blood (red) and lymphatic (green) vessels reach the graft. Antigen (Ag) and antigen-presenting cells (APCs) both of host and donor can leave the cornea using corneal lymphatics. (2) and migrate through corneal lymphatic vessels to the draining lymph nodes. (3) After stimulation of immune effector cells in the regional lymph node, T lymphocytes/effector cells can be released via the efferent blood vessels (4) and gain direct access to the transplant and initiate a rejection reaction (efferent arm of the immune reflex arc). (adopted from [4]).

In this review, we briefly discuss the known endogenous regulators of lymphangiogenesis and present the currently available methods for inhibiting the growth of blood and lymphatic vessels or inducing their regression, which are already partially clinically used. Subsequently, we will review the newly identified regulators of lymphangiogenesis and finally, we want to highlight that the cornea is an ideal model for identifying new modulators of lymphangiogenesis. 


\section{Endogenous Regulators of (lymph)angiogenesis}

Various molecular mechanism contributes to the corneal (lymph)angiogenic privilege. Up to now, various endogenous factors that promote or inhibit lymphangiogenesis have been identified. Angiogenesis and lymphangiogenesis are mainly induced by members of the vascular endothelial growth factor (VEGF) family. Binding of VEGF-A and VEGF-B to VEGFR-1 and VEGFR-2 induces hemangiogenesis [6-8]. In addition, the cytokines platelet-derived growth factor (PDGF) [9], fibroblast growth factor-2 (FGF-2), placental growth factor (PIGF), hepatocyte growth factor (HGF) [10] and the adapter protein insulin receptor substrate-1 (IRS-1) [11] have also been found to induce hemangiogenesis.

Lymphangiogenesis is mainly induced by binding of VEGF-C and VEGF-D to VEGFR-2 and VEGFR-3 [6,7,12]. However, the pro-angiogenic factor VEGF-A has also been shown to be capable of inducing lymphangiogenesis. This effect can be mediated either indirectly by the recruitment of VEGFR-1 positive macrophages, which then secrete VEGF-C and D, or directly by proliferative action on the lymphatic endothelial cells [13-15]. As with angiogenesis, there are also other growth factors, such as FGF-2 [16], PDGF [17], angiopoietin [18,19] and HGF [20], that induce lymphangiogenesis. Moreover, in a wide range of diseases, such as cancer, cardiovascular disease, and inflammation, pro-inflammatory or anti-inflammatory cytokines may induce or suppress lymphangiogenesis [21,22]. Pro-inflammatory cytokines, like interleukin (IL)-1, IL-12, IL-18, tumor necrosis factor (TNF)- $\alpha$, and interferon (IFN)- $\beta$, are produced mainly by macrophages but also by NK cells, T cells, B cells and neutrophils $[23,24]$. Cytokines such as IL-1 and TNF have been shown to induce VEGF-C expression and thus promote lymphangiogenesis [25]. On the other hand, anti-inflammatory cytokines like IL-4, IL-10, IL-11 and IL-13 are secreted by macrophages, as well as T cells, vascular smooth muscle cells and endothelial cells [23]. It was also described that the anti-inflammatory cytokines IL-4 and IL-13 downregulate the prospero homeobox 1 (Prox1) transcription factors in lymphatic endothelial cells (LECs), thus impairing lymphatic endothelial cell survival, proliferation, and migration [26,27].

Endogenous inhibitors play an important regulatory role in preserving the angiogenic privilege and inhibiting and regressing blood and lymphatic vessels induced by minor vascular stimuli. These endogenous antiangiogenic factors can be categorized into endostatin/endostatin analogues (endostatin, arresten, and tumstatin), plasminogen/serine protease inhibitors (angiostatin and pigment epithelial-derived factor [PEDF]), thrombospondin-1, -2 and soluble VEGF receptors [28-32].

Major components of the cornea are collagen fibrils of uniform diameter and proteoglycan interacting with the collagen fibers [33,34]. The stromal proteoglycans belong to the group of small leucine-rich proteins (SLPR). The SLRP has key functions in collagen fibril growth and organization, extracellular matrix (ECM) assembly, corneal transparency and in the regulation of inflammatory processes [35]. For lumican, biglycan, and decorin, the main components of the corneal SLRP, it is also discussed that they regulate the macrophage and neutrophil migration and cytokine secretion in the cornea $[35,36]$.

Fragments of the ECM collagens play a functional role in the angiogenesis process. Endostatin consists of a 20-kDa C-terminal fragment of type XVIII collagen of the ECM and is one of the most potent inhibitors of angiogenesis. It binds to different integrins $\left(\alpha_{3} \beta_{1}, \alpha_{5} \beta_{1}, \alpha_{v} \beta_{3}\right.$, and $\left.\alpha_{v} \beta_{5}\right)$, inhibits cell proliferation, and disrupts cell migration [32,37-39]. Tumstatin, a 28-kDa fragment of collagen IV, binds to integrin $\alpha_{\mathrm{v}} \beta_{3}$ and $\alpha_{\mathrm{v}} \beta_{5}$ and contains anti-angiogenic capacity. The binding to integrin $\alpha_{v} \beta_{3}$ is necessary for the antiangiogenic activity [40,41]. Another fragment of type collagen IV with anti-angiogenic properties is arresten. Arresten is the $26-\mathrm{kDa}$ fragment of the C-terminal domain of type IV collagen mediating its anti-angiogenic effects via binding to integrin $\alpha_{1} \beta_{1}$ [41].

Angiostatin, an endogenous antiangiogenic factor that is cleaved from plasminogen produced in the cornea, can attach to several surface proteins in vascular endothelial cells and hinder their migration and tubule formation [42,43].

Thrombospondins (TSPs) belongs to a family of high molecular weight glycoproteins that are secreted by most cell types and participate in cell-to-cell and cell-to-matrix communication. TSP-1 was 
the first naturally occurring protein inhibitor of angiogenesis to be identified. We have observed that TSP-1 is involved in the inhibition of corneal hemangiogenesis in vivo [44]. In this context, it has been shown that TSP-1 can inhibit hemangiogenesis both directly and indirectly [31,45]. Subsequent studies have shown that also TSP-2 inhibits angiogenesis [31].

Moreover, the cornea also expresses soluble variants of VEGFR-1, -2 and -3 which act as decoy receptors. The soluble VEGFR-1 lacks the transmembrane and tyrosine kinase domains [46] and traps secreted VEGF-A [28].

The corneal epithelium also plays a central role in maintaining the alymphatic state of the cornea. The corneal epithelium expresses the soluble forms of VEGFR-2 and -3 (sVEGFR-2, sVEGFR-3) [47,48]. The sVEGFR-2 is the monomer of the extracellular domain of the membrane-bound receptor. This soluble form results from alternative splicing and acts as an important endogenous antagonist by capturing free monomeric VEGF-C and thus preventing lymphangiogenesis [47]. On the other hand, the sVEGFR-3 is the truncated isoform of the VEGFR-3, consisting only of the extracellular ligand-binding domain of VEGFR-3 [48]. The binding of VEGF-C to sVEGFR-3 not only inhibits lymphangiogenesis [48,49], but also causes a regression of already formed lymphatic vessels [49]. The membrane-bound VEGFR-3 is an endothelium-specific receptor tyrosine kinases expresses in the fetal vasculature in venous and lymphatic endothelium. This is restricted to lymphatic endothelium in adults. However, we could show that membrane-bound VEGFR-3 expressed on the human corneal epithelial cells [1] also binds VEGF-C and thus helps maintain corneal avascularity [50].

Recent and ongoing research demonstrates that immune-mediated corneal graft rejection depends on both angiogenesis and lymphangiogenesis. Several studies show that anti-lymphangiogenic treatment exhibits success in improving graft survival $[3,47,51]$. Therefore, the identification of novel endogenous regulators contributes to a better understanding of the role of angiogenesis and lymphangiogenesis in corneal transplants, which subsequently has the potential to reduce graft rejection rates.

\section{Endogenous Regulators of Lymphangiogenesis in Corneal Transplantation}

During the past years, research has demonstrated that modulating both VEGFs and their receptors in both low- and high-risk corneal transplantation can reduce angiogenesis and lymphangiogenesis $[47,51-53]$. The potential for neovascularization can thereby be reduced and the chance of transplant survival can be increased. The same potentially also works for other forms of transplantation.

In this context, we were able to show that the use of VEGF-Trap(R1R2) to neutralize VEGF-A early postoperatively significantly reduced both hem- and lymphangiogenesis and significantly promoted long-term graft survival in a normal-risk corneal transplantation model [52]. It has recently shown that the VEGF-Trap significantly inhibits the infiltration of immune cells, including macrophages and $\mathrm{CD}^{+} \mathrm{T}$ cells. [54]. The subconjunctival administration of Bevacizumab, a neutralizing antibody for all VEGF-A isoforms, significantly diminished corneal graft opacity, prolonged the graft survival, and reduced the neovascular area and invasion area compared to topical treatment and no treatment (control) in a mouse model of high-risk corneal transplantation [55].

This approach has been transferred to the clinic and several studies have shown promising results following Bevacizumab treatment for corneal neovascularization in patients before and/or after penetrating keratoplasty. So, it could be shown that intrastromal application [56-58], topical application [59-61] and subconjunctival injection [62] respectively of Bevacizumab leads to a reduction in corneal neovascularization and so enables long term success of subsequent corneal transplantation after high-risk transplantation. Just recently, we demonstrated that the fine-needle diathermy in combination with subconjunctival injection of Bevacizumab prior to high-risk keratoplasty in patients results in graft survival rates comparable to survival rates seen in normal-risk keratoplasty [63]. Moreover, a combined subconjunctival and topical Bevacizumab treatment improves the graft survival rate in $70 \%$ of high-risk transplantations during three years of follow-up [60]. 
Another approach that has been used in clinical trials to suppress the growth of lymphatic vessels is the blockade of the insulin receptor substrate (IRS-1). IRS-1 is a cytosolic adapter protein without intrinsic kinase activity that recruits other proteins to their receptors [64]. Using antisense oligonucleotide against IRS-1 we have observed reduced proliferation of human dermal lymphatic endothelial cells. The additional blockade of IRS-1 reduces the expression of VEGF-A, but not the expression of VEGF-C, VEGF-D, and VEGFR-3. Treatment with IRS-1 antisense oligonucleotide also inhibits inflammation-induced lymphangiogenesis in a murine suture-model [53]. The IRS-1 antisense oligonucleotide has now passed through phase II and III trials and demonstrates a significant inhibition of corneal neovascularization in patients [65].

In addition to the inhibitors of angiogenesis described above, which have meanwhile found use in the clinic, some endogenous inhibitors of lymphangiogenesis are also known. In recent years, however, these have only been studied preclinically for their potential of improving graft survival.

The role of lymphatics in transplantation and the effects of VEGF-C and VEGF-D blockade on soluble VEGFR-3 (sVEGFR-3) on corneal neovascularization and graft survival have recently been investigated. The treatment with sVEGFR-3 resulted in a significant blockade of lymphangiogenesis two weeks after transplantation. Moreover, significantly prolonged corneal allograft survival compared to the control group at eight weeks after transplantation could be observed. This was associated with significantly reduced frequencies of allosensitized $\mathrm{T}$ cells and decreased frequencies of IFN- $\gamma$-producing $\mathrm{CD}^{+} \mathrm{T}$ cells [51]. There is evidence that the primary cellular mediators of immune rejection are predominantly mediated by $\mathrm{CD} 4^{+} \mathrm{T}$ cells [66].

The blockade of VEGF-C by sVEGFR-2 is essential for corneal alymphaticity. Moreover, intracorneal administration of sVEGFR-2 reduced lymphangiogenesis, enhanced corneal allograft survival and suppressed lymphangioma cellular proliferation in a corneal transplantation model [47].

To investigate the role of existing lymphatic vessels in graft rejection the murine model of corneal transplantation [3] with different experimental conditions in the recipient was used: 1. normal-risk (healthy avascular recipient bed), 2. high-risk (recipient bed vascularized with blood and lymphatic vessels) and 3. alymphatic high-risk (recipient bed vascularized only with blood vessels, the outgrowth of lymphatic vessels was inhibited by the VEGFR-3 Ab mF4-31C1 treatment) (Figure 2A,B). Target inhibition of lymphangiogenesis during the inflammatory vascularization phase prior to corneal transplantation the survival of the graft used in the alymphatic bed was significantly improved compared to the graft used in the high-risk recipient bed. Even more, the survival of the graft under alymphatic conditions was comparable to the survival under low-risk conditions [3].

Also blocking VEGF-C with an anti-VEGF-C (VGX-100) antibody in a murine model of high-risk transplantation showed effectively reduced graft lymphangiogenesis in comparison to the untreated control group. This treatment significantly improved the eight-week graft survival compared to control [54]. Furthermore, the administration of anti-VEGF-C not only suppresses the corneal angiogenic responses but also inhibits trafficking and maturation of APCs [67].

Podoplanin, a mucine-type glycoprotein, is highly expressed on lymphatic endothelial cells but not on arterial and venous endothelial cells in the vascular system. The surface receptor C-type lectin-like receptor 2 (CLEC-2) is expressed on dendritic cells, neutrophils, and platelets and binds to podoplanin $[68,69]$. Moreover, podoplanin also binds CCL21 with high affinity [70] and this interaction has implications for lymphocyte trafficking, as LECs express CCL21 to direct lymphocyte and DC trafficking to the LNs [71]. Recently, the influence of podoplanin on graft rejection has been examined. The administration of anti-podoplanin antibodies both inhibits the growth of the lymphatic vessels and drastically reduces the infiltration of macrophages. Moreover, the rejection reaction in the corneal transplantation model is also significantly suppressed [72].

Integrins are a family of heterodimeric transmembrane glycoproteins mediating cell-cell and cell-ECM connections. Some of the integrins play an important role in angiogenesis or lymphangiogenesis. However, the integrins that regulate lymphangiogenesis are different from those that regulate angiogenesis [73]. Integrin $\alpha_{9} \beta_{1}$ plays a critical role in lymphangiogenesis, 
since integrin $\alpha_{9} \beta_{1}$ promotes VEGF-C and D stimulated cell migration by directly binding these growth factors [8,74]. In order to analyze the function of integrin $\alpha_{9} \beta_{1}$, corneal transplantation between fully mismatched mice was performed. The recipients received subconjunctival injections of either integrin $\alpha_{9}$ blocking antibody or isotype control twice a week for eight weeks. The treatment with an anti-integrin $\alpha_{9}$ blocking antibody does not affect corneal lymphangiogenesis. However, they demonstrated that the treatment suppressed lymphatic valvulogenesis after transplantation whereby a higher rate of graft survival was achieved [75].
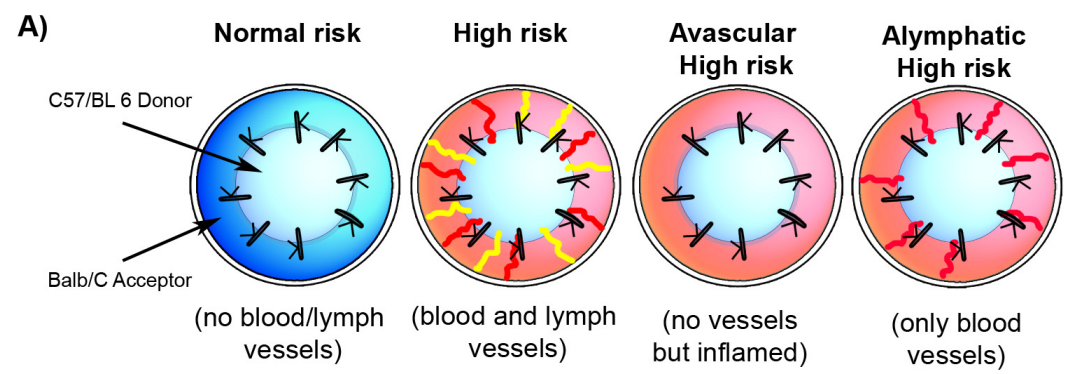

B)

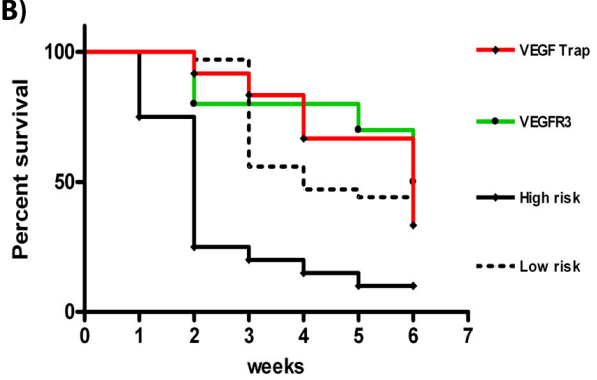

C)
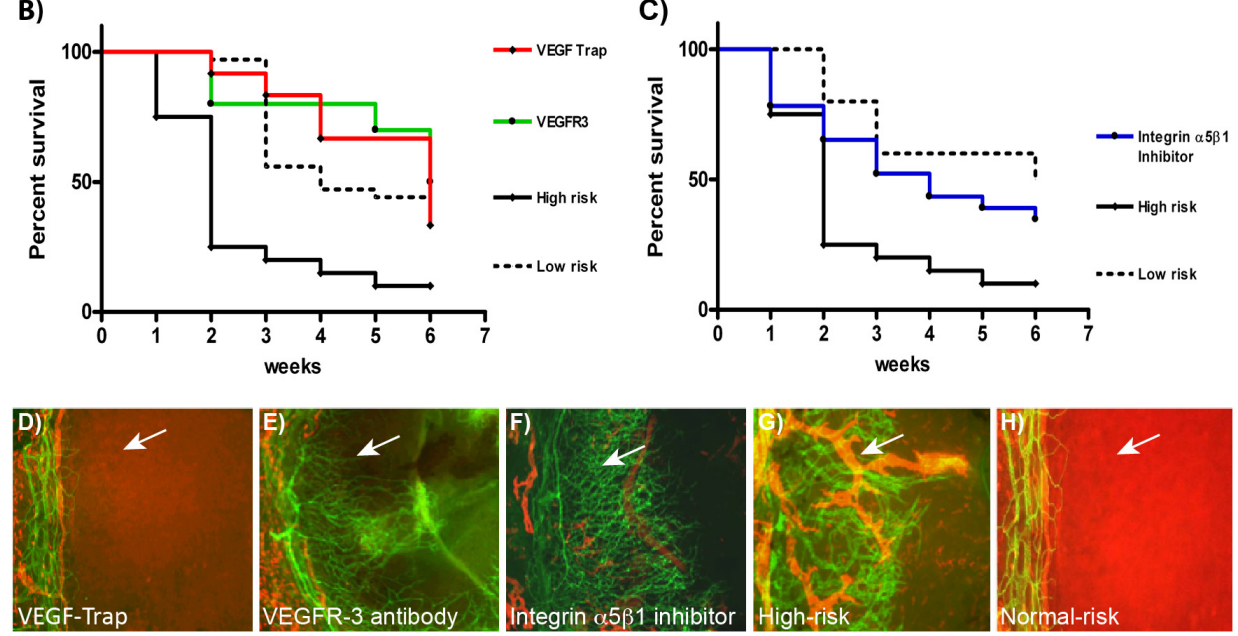

Figure 2. Lymphatic vessels in the recipient bed prior to transplantation determine graft survival. (A) Schematic diagram showing transplantation models normal-risk (avascular), high-risk (inflamed and hemvascularized and lymphvascularized), avascular high-risk (inflamed, avascular), and alymphatic high-risk recipient beds (inflamed and hemvascularized, but no lymphatic vessels). (B) and (C) Kaplan-Meier survival curve. To induce inflammation the suture-induced corneal neovascularization assay was performed two weeks prior transplantation and mice were treated with vascular endothelial growth factor (VEGF)-Trap R1R2 $(\boldsymbol{B}$ (red line) and $\boldsymbol{D}$; no blood and lymphatic vessels, but reduced inflammation in the recipient bed), VEGFR-3 Ab (mF4-31C1) ( $\boldsymbol{B}$ (green line) and $\boldsymbol{E}$; only blood vessels present in the recipient bed), or integrin $\alpha_{5} \beta_{1}$ inhibitor (JSM6427) ( $C$ (blue line) and $\boldsymbol{F}$; only blood vessels present in the recipient bed). Graft survival was compared with prehemvascularized and prelymphvascularized controls ( $\boldsymbol{B}$ and $\boldsymbol{C}$ (black line), $\boldsymbol{G}$ : "high-risk" recipient bed) and avascular recipient controls ( $\boldsymbol{B}$ and $\boldsymbol{C}$ (dotted line), $\boldsymbol{H}$ : “low-risk" recipient bed). The graft survival was significantly better when transplants were placed into recipient beds lacking lymphatic vessels compared with beds with lymphatic vessels present. (VEGF-Trap versus high-risk: $p<0.0001$; VEGFR-3 versus high-risk: $p<0.0002 ; n=10$; JSM6427 versus high-risk: $p<0.032, n=23$; Kaplan-Meier survival curve). ( $\boldsymbol{D}-\boldsymbol{H})$ Corneal whole mounts stained for blood vessels (CD31, green) and for lymphatic vessels (LYVE-1, red) in different recipient beds. Representative images of recipient corneal beds at the time of transplantation after corneas were treated with (D) VEGF-Trap 1 1R2, (E) VEGFR-3 (mF4-31C1), (F) integrin $\alpha_{5} \beta_{1}$ inhibitor (JSM6427), or (G) untreated high-risk and $(\mathbf{H})$ normal-risk (original magnification $\times 100$ ). Arrow, prevascularized cornea. (modified from [3]). 
Integrin $\alpha_{5} \beta_{1}$ is expressed by a subpopulation of lymphatic vessels in the inflamed cornea [3], but it does not appear to play a role in tumor lymphangiogenesis [76]. To analyze the impact of the integrin $\alpha_{5} \beta_{1}$ in high-risk corneal transplantation, the small-molecule antagonists JSM6427 was used to inhibit integrin $\alpha_{5} \beta_{1}$ function. The treatment with the antagonists led to specific inhibition of lymphangiogenesis, while hemangiogenesis was not affected significantly. Thus, the systemic inhibition of integrin $\alpha_{5} \beta_{1}$ and, thereby, the absence of lymphatic vessels in the recipient bed significantly improved corneal graft survival after high-risk corneal transplantation compared to control and reduced the risk for rejection to the level of low-risk corneal transplantation [3] (Figure 2C).

Semaphorins, initially described as axon guidance factors, have recently been implicated in a variety of physiological and developmental functions including regulation of immune response, angiogenesis, and migration of neural crest cells [77]. Members of the class 3 semaphorins are soluble ligands that bind to the neuropilin and plexin receptors [78,79]. Semaphorin-3F (Sema-3F) a member of the class 3 semaphorins is a known mediator contributing to the anti-angiogenic barrier in the eye $[80,81]$. Recently, a strong expression of Sema3F in the corneal epithelium of both naive murine and healthy human cornea could be detected. However, under inflamed condition, Sema-3F was significantly downregulated. Topical application of recombinant Sema-3F significantly inhibits the outgrowth of corneal lymphatic vessels and increases the graft survival in the murine model of high-risk corneal transplantation [82].

In conclusion, the blockade of podoplanin, the inhibition of integrin or the treatment with Sema-3F could be used as promising new therapeutic targets in improving graft rejection.

\section{Identification of Novel Endogenous Regulators of Lymphangiogenesis}

\subsection{Proteins and Peptides in Lymphangiogenesis}

In recent years, only a few novel endogenous modulators of lymphangiogenesis have been identified. Some of these were already known inhibitors of angiogenesis, in which now an inhibitory function in lymphangiogenesis was also determined. Additionally, we and others were able to further identify new regulators of lymphangiogenesis. These regulators help to better understand the regulation of lymphangiogenesis. In the cornea, beside the above mentioned sVEGFR-2 [47], sVEGFR-3 (sVEGFR-3) [48,49], and the membrane-bound VEGFR-3, thrombospondin (TSP)-1 [83], vasohibin-1 [84] and neuropilin (NP-2) [85] were also identified and accepted as endogenous inhibitors.

We were able to show that TSP-1 inhibits not only hemangiogenesis but also lymphangiogenesis. TSP-1 binds to CD36 on macrophages and leads to an inhibition of VEGF-C production in these macrophages, which in turn leads to an inhibition of lymphangiogenesis [83].

Vasohibin-1 (VASH1), a novel inhibitor of angiogenesis is selectively expressed in endothelial cells (EC). Its expression is induced by growth factors such as VEGF and FGF-2 and it inhibits the migration, proliferation, and tube formation of ECs [86]. Recently, it was observed that vasohibin-1 also inhibited VEGF-C-stimulated lymphangiogenesis supports a direct anti-lymphangiogenesis activity of vasohibin-1 [84].

Neuropilin-2 (NP-2) is associated with VEGFR-3 and mediates lymphatic vessel sprouting in response to VEGF-C [85]. The artificial microRNA (amiRNA) targeting NP-2 has been shown to efficiently reduced NP-2 expression in lymphatic endothelial cells. Furthermore, the subconjunctival application of NP-2 amiRNA improved graft survival in high-risk transplantation model [87].

Matrix metalloproteinases (MMPs) are endopeptidases essential for tissue remodeling and signal transduction in processes ranging from growth and development to cancer progression, metastasis, and angiogenesis [88,89]. Membrane type-1-matrix metalloproteinase (MT1-MMP) is a membrane-bound metalloproteinase that is essential for diverse physiological processes like extracellular matrix remodeling and pericellular proteolysis [90]. The cleavage of VEGFR-1 by corneal MT1-MMP results in a VEGF-Trap effect that reduces the proangiogenic effect of VEGF-A 165 and thus corneal angiogenesis [91]. Furthermore, MT1-MMP deficient mice have defective fibroblast 
growth factor-2 (FGF2) induced corneal angiogenesis [92,93]. So, MT1-MMP has been identified as a crucial regulator of blood vessel growth. It has been recently shown that MT1-MMP directly cleaves LYVE-1 on lymphatic endothelial cells and thereby inhibits LYVE-1-mediated lymphangiogenic responses. Therefore, MT1-MMP is also an endogenous inhibitor of corneal lymphangiogenesis [94]. Besides MT1-MMP, the cornea also expresses MMP-2 and MMP-9. Using the selective inhibitor SB-3CT for MMP-2 and MMP-9, it has been demonstrated that also MMP-2 and MMP-9 are critically involved in corneal lymphangiogenesis during inflammatory response [95].

Aqueous humor is a clear body fluid in the anterior and posterior chamber of the eye. Its function is to supply the lens and the cornea with nutrients and remove potentially harmful agents. Moreover, it also contains several immunomodulatory factors. Just recently, we have shown that the aqueous humor exerts anti-hem- and anti-lymphangiogenic effects in vivo and in vitro [96]. Thereby, we have demonstrated that the immunomodulatory factors $\alpha$-melanocyte-stimulating hormone ( $\alpha$-MSH) and vasoactive intestinal peptide (VIP) contained in the aqueous humor partially mediate the anti-lymphangiogenic effect [96]. These results demonstrated that aqueous humor contributes to the corneal (lymph)angiogenic privilege.

\subsection{Non-Coding RNAs in Lymphangiogenesis}

In recent years, non-coding RNAs (ncRNA) have gained more and more attention. NcRNAs are functional RNA molecules that have the ability to control gene expression. NcRNAs are divided into small/short ncRNAs (miRNA, piRNA, siRNA, etc.) and long ncRNAs (lncRNAs) [97]. Over the last few years, various miRNAs and lncRNAs that have an influence on hem- and lymphangiogenesis have been identified.

MicroRNAs (miRNA), a class of small ncRNAs of approximately 21-24 nucleotides (nt) in length [98, 99], have been shown to play different roles in human organ transplantations [100,101]. However, there are only a few reports on miRNAs being directly associated with corneal transplant rejection.

The search for differentially expressed miRNA in isograft corneas vs. normal corneas, as well as in allograft corneas vs. isograft corneas could recently identify altered levels of four miRNAs in both groups [102]: miR-155-5p, miR-142-3p, miR-142-5p, and miR-223-3p. Using a penetrating keratoplasty model demonstrated high expression of miR-122 in the corneal stroma and it has been observed that the increased miR-122 expression significantly decreases the risk of corneal transplantation rejection [103]. However, further investigations are needed to understand the underlying mechanism.

In addition to their involvement in the rejection response of corneal grafts, miRNAs expressed in the cornea have recently been further identified to have a direct or indirect influence on lymphangiogenesis. Recently, a significantly reduced expression of miR-184 was observed in inflamed cornea compared to naive cornea. This is accompanied by reduced lymphangiogenesis [104]. Furthermore, overexpression of miR-184 in LECs in vitro suppresses adhesion as well as migration capacity and reduces the ability to organize into capillary-like tubes [104]. This also reveals that miR-184 is a negative regulator of the lymphangiogenic process.

Prox1, a transcription factor whose activity is important for lymphatic vessel development and maintenance [105-107], is mainly expressed in lymphatic endothelial cells and it has no influence on the development and function of blood vessels [107]. However, very little is known about the underlying mechanisms. When comparing embryonic blood endothelial cells with lymphoid endothelial cells, a significantly higher expression of miR-181a was observed. Furthermore, a specific consensus binding site for miR-181a was observed in the $3^{\prime}$ untranslated region (UTR) of Prox1. Direct binding of miR-181a to the 3'UTR of Prox1 results in rapid degradation of Prox1 mRNA. [108]. This way, miR-181 activity silenced Prox1 expression in the blood vasculature during development [108]. By determining the miRNA expression profiles of human LEC and blood endothelial cells (BECs), it could be shown that another miRNA (miR-31) is highly expressed in blood endothelial cells and binds to $3^{\prime}$ UTR of Prox1 resulting in the degradation of Prox1 mRNA [109]. Just recently, miR-466 has been identified as a new prospect to target the $3^{\prime}$ UTR of Prox1 [110]. 
VEGFR-3 proved to be important for developmental angiogenesis and lymphangiogenesis [111]. VEGFR-3 expression is maintained on all endothelial cells during development, but it becomes restricted to lymphatic endothelial cells in adulthood [112]. The transcription factor Prox1 [113] is decisive for VEGFR-3 expression, which explains the indirect regulation of VEGFR-3 in naive BECs by the above-mentioned miRNAs which regulate Prox-1. The mechanism, however, by which VEGFR-3 is controlled during inflammatory lymphangiogenesis is not completely understood. The induction of miR-1236 in lymphatic endothelial cells by the inflammatory cytokine IL-1 $\beta$ leads to translational inhibition of VEGFR-3, whereas the expression of VEGFR-2 is not altered [114]. On the other side, it was observed that miR-9 increases VEGFR-3 expression in LECs and promotes lymphatic tube formation [115]. More recently, miR-126 has been demonstrated to specifically regulates lymphatic development in part by modulating VEGFR-3 signal transduction. Also, LECs reacts poorly to VEGF-A and VEGF-C through reducing the expression of VEGFR-2 and VEGFR-3 after miR-126 inhibition. [116].

The Discoidin domain receptors family member 1 (DDRs) 1 is expressed on epithelial cells, endothelial cells, and tumor cells [117-119] and interact with almost all types of collagen, including fibrillar collagens I-III $[120,121]$. Activation of DDR1 triggered by collagen-binding induces cell proliferation, tumor angiogenesis, and lymphangiogenesis [118,122]. Reduced expression of both the mRNA and the protein levels of DDR1 by miR-199a/b-5p lead to reduced tube formation in human LEC cells whereas an inhibitor of miR-199a/b-5p increases DDR1 expression and enhances tube formation in LECs. Moreover, the use of a corneal alkali-burn model, revealed that one subconjunctival injection of miR-199a/b-5p mimics not only suppressed DDR1 expression but also significantly reduced lymphangiogenesis in comparison to scramble control [118].

LncRNAs, on the other hand, are defined as transcripts longer than $200 \mathrm{nt}$ that are not translated into protein. Several studies suggest that lncRNAs play a role in either negative or positive regulation of gene expression at both transcriptional and post-transcriptional levels in development and differentiation [123-125]. Many lncRNAs have been functionally associated with human diseases, particularly the development and progression of human cancers [126]. However, little is known about the expression of IncRNAs in the eye. Recently, it has been demonstrated that the expression pattern of IncRNA exhibits distinct changes during maturation between P0 and 8 weeks of age as well as tissue specificity within the cornea, lens, retina, RPE, choroid, and sclera. This result seems to be consistent with the idea that lncRNA may be important in maintaining tissue identity [127]. The involvement of lncRNA H19 in neovascularization has recently described with lncRNA H19 acting as a molecular sponge for miR-29c to regulate the expression of VEGF-A [128].

However, only a few studies to date are known that describe the influence of IncRNA in lymphangiogenesis. It has been shown that the antisense non-coding RNA in the INK4 locus (ANRIL) is significantly overexpressed in patients with colorectal cancer and correlates with higher expression of VEGF-C, VEGFR-3, and LYVE-1 [129]. The overexpression of IncRNA BLACAT2 (bladder cancer-associated transcript 2) promotes lymphatic metastasis by regulation of VEGF-C expression [130].

The data show that both miRNA and lncRNA are involved in the regulation of both hemangiogenesis and lymphangiogenesis. Therefore, they may be a promising therapeutic target. However, further studies are needed to better understand both miRNAs and lncRNAs in the regulation of hemangiogenesis and lymphangiogenesis.

\section{Murine Cornea is a Suitable Model for Identification of Novel Endogenous Modulators of Lymphangiogenesis}

A recent approach for the identification of new modulators of hem- and lymphangiogenesis is the comparison of naive or inflamed corneas of divergent mouse strains. With such an approach, the genetic heterogeneity of angiogenesis has been confirmed several years ago. The study found an up to a 10-fold difference in corneal blood vessel growth in response to FGF-2 and VEGF [131]. A follow-up study further analyzed the angiogenic responsiveness to FGF-2 and VEGF which led to 
the identification of several quantitative trait loci (QTL). QTL analysis is used to combine phenotypic information (e.g., vascular growth) and genotype data to identify chromosomal regions that contribute to the observed variation in the feature being analyzed. Thereby, they could identify six regions on chromosome 2, 4, 10, 13, 15, and 18 responsible for the VEGF and FGF-2 responsiveness [132,133].

Since the discovery of lymphatic markers like LYVE-1 and VEGFR-3, research in genetic heterogeneity of lymphangiogenesis experiences more attention. Recently, we were able to identify further novel regulators of lymphangiogenesis by analyzing the differences between different mouse strains concerning lymphatic vessels could be found in a physiological situation. For that purpose, we determine the limbal lymphatic vascular and counted the number of the vascular extensions (sprouts) from the main limbal lymphatic vessel into the avascular cornea from whole mounts of naive eyes. The determination of the total area of the limbal lymphatic vessel and the physiological extension showed that $\mathrm{BALB} / \mathrm{c}$ has the lowest resting limbal lymph vascular area. The area of the resting limbal vasculature varied significantly between 1.4-fold for $129 \mathrm{~S} 1$ and 1.8-fold for C57BL/6 compared to BALB/c (Figure 3). We also observed significant differences in the number of physiological extensions in the avascular cornea. The numbers of extension into the avascular cornea are 1.5-fold higher in C57BL/6 and 1.6-fold higher in SJL and FVB in comparison to BALB/c [134]. Furthermore, we compared the limbal lymphatic vasculature in corneal inflammatory lymphangiogenesis and VEGF-C induced lymphangiogenesis to analyze the presence of strain-dependent differences in lymphatic vessel growth. The results clearly show that, depending on the mouse strain, the lymph vascular surface induced by VEGF-C varied up to 1.9-fold. The lymph vascular surface induced by the suture-induced inflammatory corneal neovascularization model also varied up to 1.7-fold depending on the mouse strain. This shows that the genetic background is an important predictor for the extent of growth factor-induced (VEGF-C) and inflammation-induced lymphangiogenesis. The data shows significant differences in the lymphangiogenic response between the different classical and wild-derived inbred strains and this suggests underlying genetic factors influencing the lymphangiogenic response [134].
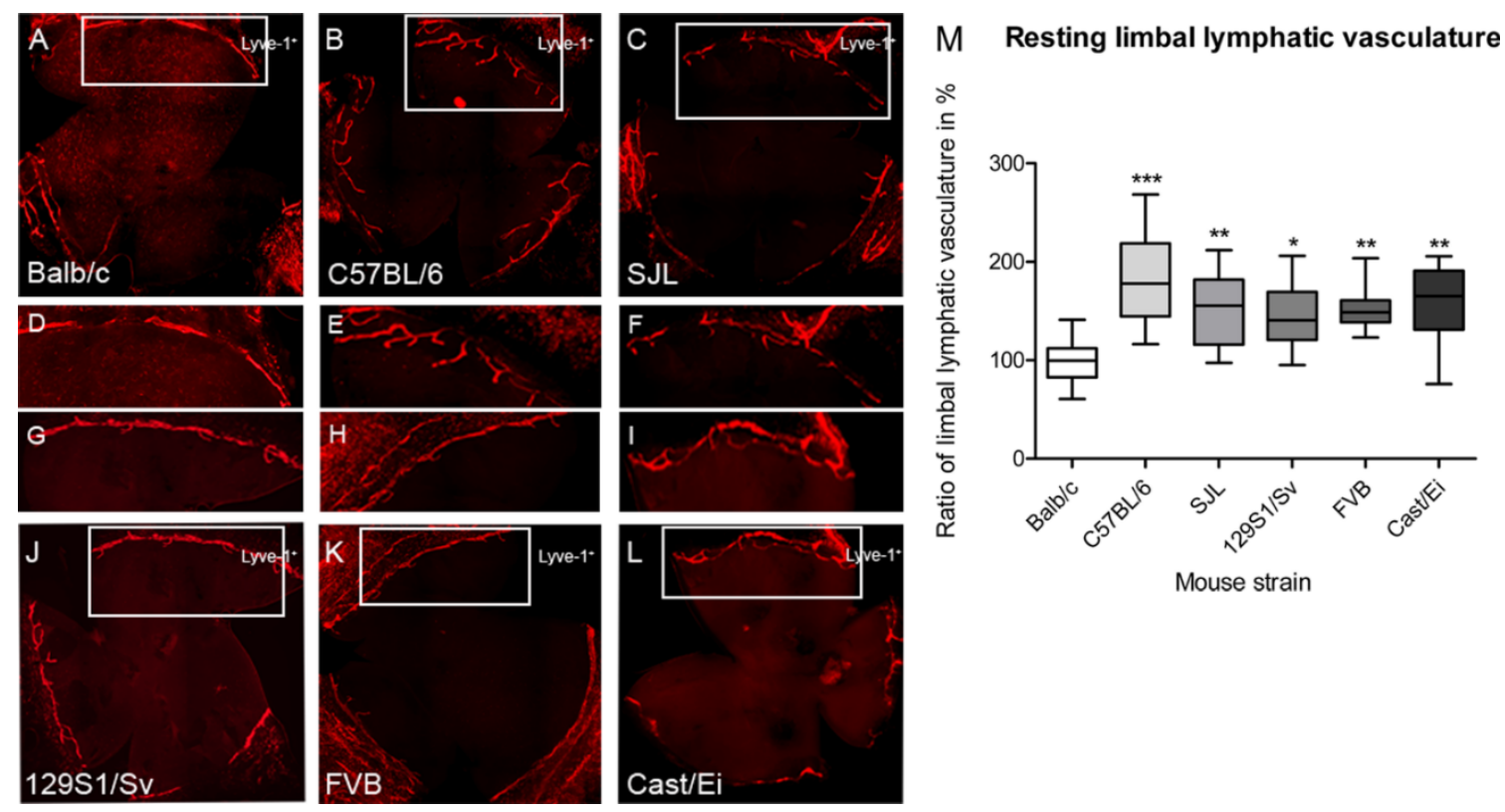

Figure 3. Lymphvascularized area of naive corneas from different inbred and wild-type mice strains. (A-L): Whole mounts of murine naive corneas stained with LYVE-1) with resting limbal vasculature (original magnification $\times 100$ ). (A) BALB/c (B) C57BL/6N (C) SJL/J (J) 129S1/S (K) FVB/N (L) Cast/E. D-I) Higher magnification of the limbal vasculature of the strains. (M) Quantification of the area of the resting limbal lymphatic vasculature. Statistical analysis was done by Kruskal-Wallis test with Dunn's multiple comparison post-test. ${ }^{*} p<0.05,{ }^{* *} p<0.01,{ }^{* * *} p<0.001$. (modified from [134]). 
To analyze whether the phenotypic differences correlate in the differential expression of individual genes between the strains, we compared the naive cornea of the highly lymphangiogenic C57BL/6 mouse and the low lymphangiogenic BALB/c mouse with the pathway-specific expression analysis. We identified 13 differentially regulated genes in the cornea of C57BL/6 mice compared to BALB/c mice. Among the identified genes were already known genes that affect the lymphangiogenesis, such as thrombospondin. This shows that the method is suitable for identifying new endogenous modulators. Two of these thirteen differently expressed genes, tumor necrosis factor (ligand) superfamily member 10 (Tnfsf10/Trail) and plasminogen activator tissue (Plat/tPA), showed markedly higher expression in the BALB/C mice compared to the C57BL/6 animals. Furthermore, we identified that besides mRNA expression Trail and tPA are also expressed on protein level in the cornea of both strains. Moreover, we could demonstrate that both Trail and tPA inhibit the proliferation of LECs [135]. The data demonstrate that Trail and tPA may contribute to the lymphangiogenic privilege of the cornea.

Lymphangiogenesis is a quantitative trait that can be reliably quantified by the determination of morphometric parameters in the mouse cornea [136]. Using this, two phenotypically different mouse strains, the low-lymphangiogenic $\mathrm{BALB} / \mathrm{cN}$ and the high-lymphangiogenic $\mathrm{C} 57 \mathrm{BL} / 6 \mathrm{~N}$, were crossed to generate a population showing genetical and phenotypic variance. To perform a QTL analysis, five morphometric parameters, the lymph vessel area, the lymph vessel length, the number of vascular extensions from the major limbal lymph node, the number of endpoints, and the number of branching points, each relative to the total corneal area of interest, were determined in a large $\mathrm{BALB} / \mathrm{cN} \times \mathrm{C} 57 \mathrm{BL} / 6 \mathrm{~N}$ F2 intercross $(n=795)$, were determined and related to the cornea. Based on the results of the QTL analysis a particular strong genome-wide significant locus was identified on chromosome 7 containing tyrosinase as a potential new candidate gene contributing to the differences in limbal lymphatic vessel architecture in BALB/c and C57BL/6 mice. To validate that tyrosinase is involved in lymphangiogenesis C57BL/6 mice were compared with C57BL/6 mice carrying an albino mutation in the tyrosinase gene. Albino C57BL/6 (B6N-Tyr ${ }^{\mathrm{cBrd}}$ ) mice showed significantly increased limbal lymph vascularized areas, a higher number of lymphatic vessel endpoints and branching points in the naive cornea compared to C57BL/6 mice. In addition, the albino C57BL/6 mice also showed increased inflammation-induced lymphangiogenesis in comparison to C57BL/6 animals. These findings confirm that tyrosinase is a novel regulator of lymphangiogenesis in developmental and inflammatory lymphangiogenesis [137] (Figure 4).

These results clearly demonstrate that genetically distinct mouse strains are useful for identifying new moderators of lymphangiogenesis, like Trail, tPA, and tyrosinase, and that the cornea is an ideal model for identifying these modulators. 
A
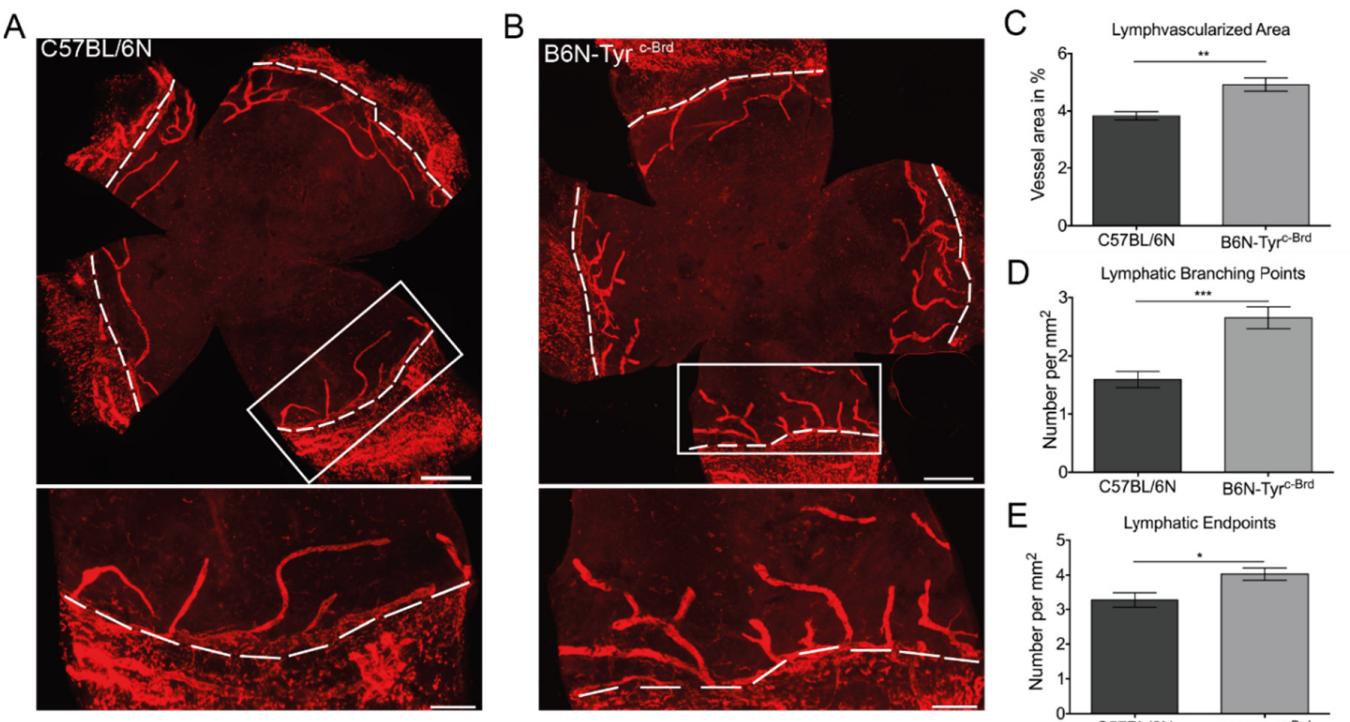

$\mathrm{D}$
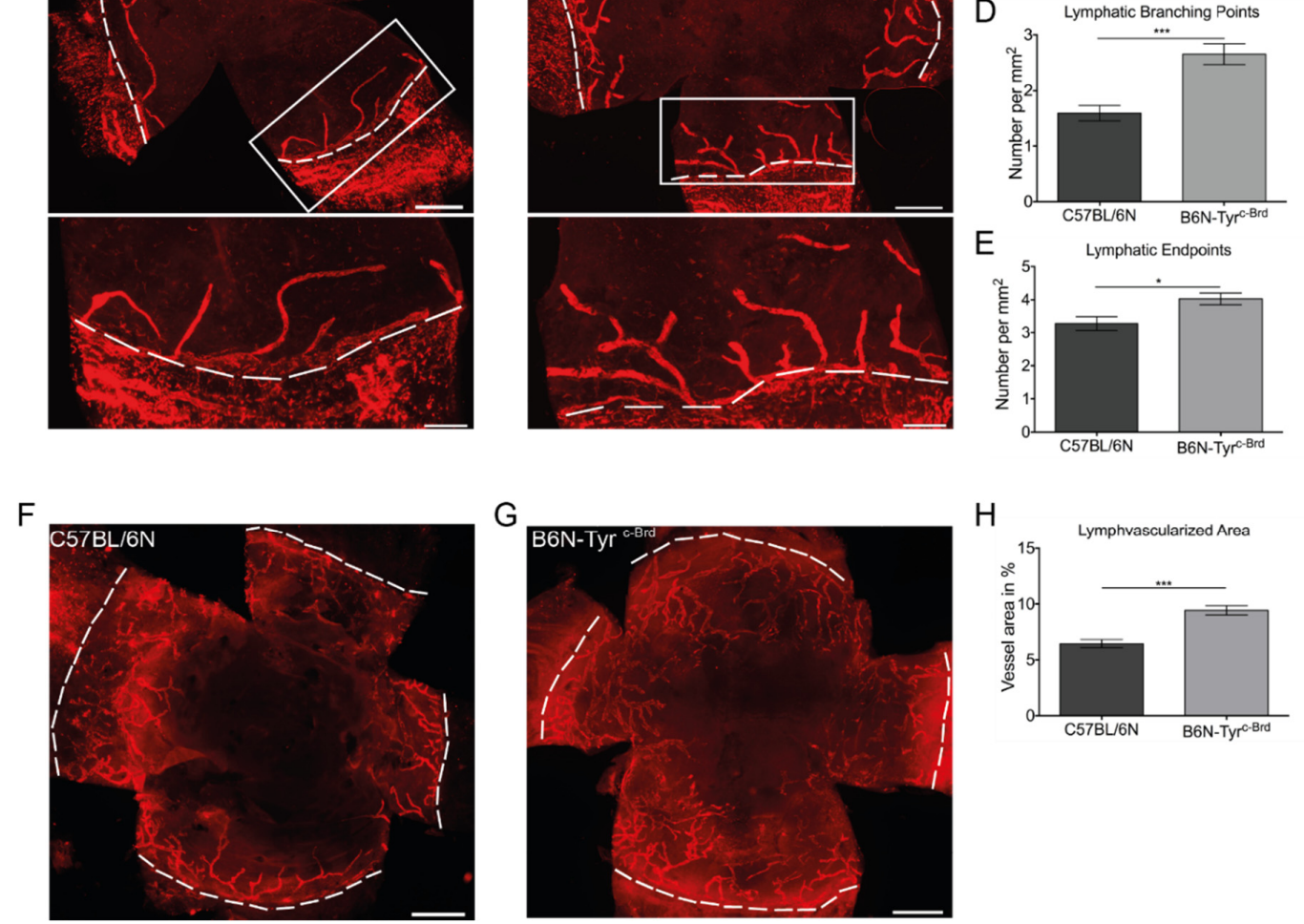

$\mathrm{H}$

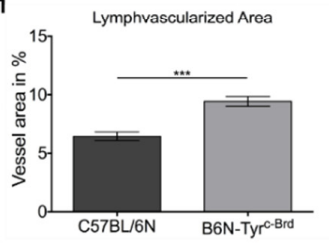

Figure 4. Absence of tyrosinase leads to increased developmental and inflammation-induced lymphangiogenesis (comparing C57BL/6N with B6N-Tyr ${ }^{\mathrm{c}-\mathrm{Brd}}$ ). (A) and (B) Corneal whole mounts of the murine cornea from C57BL/6N (A) and B6N-Tyr ${ }^{c-B r d}$ (B) stained for LYVE-1. The boxed areas show in higher magnification of the limbal vasculature in the bottom panels. (C) Quantification of the lymphatic vascularized area of the whole mounts and determination of the number of branching points (D) and the number of endpoints (E). Results are presented as the average of C57BL/6N and B6N-Tyr ${ }^{c-B r d}$ mice. F) and G): Corneal whole mounts of inflammation-induced lymphangiogenesis of C57BL/6N (F) and B6N-Tyr ${ }^{c-B r d}(G)$ stained for LYVE-1. (H) Quantification of the inflammatory lymphatic vascularized area of the whole mounts. Dashed lines show the border between the limbus and the cornea. Statistical significance was calculated by two-tailed t-test. Data are expressed as means

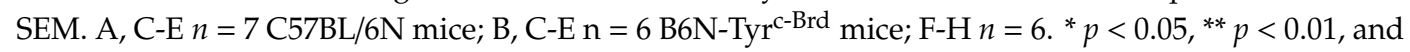
${ }^{* * *} p<0.001$. Scale bars: $500 \mathrm{~mm}$ (A and $\mathbf{B}$, upper panels, $\mathbf{F}$, and $\left.\mathbf{G}\right) ; 200 \mathrm{~mm}$ (A and $\mathbf{B}$, lower panels). Original magnification, $100 \times$ (A, B, F, and G). (adopted form [137]).

\section{Conclusions}

In recent years, it has been clearly demonstrated that, in addition to blood vessels, the non-visible lymphatics are also involved in the rejection reaction of corneal transplants. The modulation of the blood and lymph vessels before and after cornea transplantation, therefore, represents a good therapy option to improve the survival of the graft. In addition to the already known modulators, further new regulators of lymphangiogenesis (Table 1) have been described in recent years using increasingly sophisticated analytical methods and procedures. In addition to various proteins, these include ncRNA (miRNA, lncRNA) which also influence lymphangiogenesis. These novel identified factors may be promising therapeutic targets for the treatment of pathological lymphangiogenesis in a variety of ocular and extraocular diseases such as graft rejection, tumor metastasis, and dry eye disorders. 
Table 1. Proteins and non-coding RNA (ncRNA) involved in regulating (lymph-)angiogenesis.

\begin{tabular}{|c|c|c|c|}
\hline \multicolumn{4}{|c|}{ Proteins in Lymphangiogenesis } \\
\hline \multirow{4}{*}{ Endostatin } & Protein & Function & \\
\hline & Endostatin & inhibition of angiogenesis & {$[32,37-39$} \\
\hline & Tumstatin & inhibition of angiogenesis & {$[40,41]$} \\
\hline & Arrestin & inhibition of angiogenesis & [41] \\
\hline Plasminogen & Angiostatin & inhibition angiogenesis & {$[42,43]$} \\
\hline \multirow[t]{2}{*}{ Thrombospondin } & TSP-1 & inhibition of angiogenesis and lymphangiogenesis & {$[44,83]$} \\
\hline & TSP-2 & inhibition of angiogenesis & [31] \\
\hline \multirow[t]{3}{*}{ soluble VEGFR } & sVEGFR-1 & decoy receptor for VEGF-A; inhibition of angiogenesis & {$[28,46]$} \\
\hline & sVEGFR-2 & decoy receptor for VEGF-C and -D; inhibition of lymphangiogenesis & [47] \\
\hline & sVEGFR-3 & decoy receptor for VEGF-C and -D; inhibition of lymphangiogenesis & [48] \\
\hline adapter protein & IRS-1 & treatment with antisense oligonucleotide inhibits hem- and lymphangiogenesis & [65] \\
\hline Glycoprotein & Podoplanin & implication in lymphocyte trafficking, blocking antibody inhibits lymphangiogenesis & {$[71,72]$} \\
\hline \multirow[t]{2}{*}{ Integrine } & Integrin $\alpha_{5} \beta_{1}$ & treatment with antagonist JSM6227 inhibits lymphangiogenesis & [3] \\
\hline & Integrin $\alpha_{9} \beta_{1}$ & blocking antibody improves graft survival & {$[75]$} \\
\hline Semaphorine & Semaphorin-3F & contributing to anti-(lymph) angiogenic barrier & {$[82]$} \\
\hline Vasohibin & VASH-1 & negative feedback; regulator inhibition of angiogenesis and lymphangiogenesis & {$[84,86]$} \\
\hline transmembrane Receptor & Neuropilin-2 & associated with VEGFR-3, artificial miRNA improves graft & [87] \\
\hline \multirow[t]{2}{*}{ Metalloproteases } & MT-MMP1 & cleavage of VEGFR-1 and LYVE-1 & {$[91,94]$} \\
\hline & MMP-2 \& MMP9 & blockade with SB-3CT inhibits lymphangiogenesis & [95] \\
\hline \multirow[t]{2}{*}{ Peptide hormone } & VIP & inhibition of lymphangiogenesis & [96] \\
\hline & $\alpha-\mathrm{MSH}$ & inhibition of lymphangiogenesis & {$[96]$} \\
\hline TNF/TNFR-Superfamily & Trail & inhibition of lymphangiogenesis & [135] \\
\hline Proteases & $\mathrm{tPA}$ & inhibition of lymphangiogenesis & [135] \\
\hline Membrane protein & Tyrosinase & inhibition of lymphangiogenesis & [137] \\
\hline \multicolumn{4}{|c|}{ ncRNAs in Lymphangiogenesis } \\
\hline & Targets & Function & \\
\hline miRNA-184 & LECs & suppresses migration and adhesion & [104] \\
\hline miRNA-181a & Prox-1 & degradation of Prox-1 & [108] \\
\hline miRNA-31 & Prox-1 & degradation of Prox-1 & [109] \\
\hline miRNA-466 & Prox-1 & degradation of Prox-1 & [110] \\
\hline miRNA-1236 & VEGFR-3 & inhibition of VEGFR-3 & [114] \\
\hline miRNA-9 & VEGFR-3 & increased VEGFR-3 expression & [115] \\
\hline miRNA-126 & VEGFR-2/VEGFR-3 & modulates VEGFR-2 and VEGFR-3 signal transduction & [116] \\
\hline miRNA-199a/b5p & DDR1 & degradation of DDR1 & [118] \\
\hline
\end{tabular}


Author Contributions: T.C. wrote the manuscript; C.B., N.H., A.R., and C.C. revised the manuscript. All authors have read and agreed to the published version of the manuscript.

Funding: This work is supported by German Research Foundation (DFG) research unit FOR2240 (www.FOR2240.de) Cl751/1-1 (T.C.), Re 679/20-1 (A.R.) and Re3777/1-1 and Cu 47/9-2 (C.C.) and EU COST CA18116 (C.C.) and CMMC Cologne.

Acknowledgments: The authors would like to DFG research unit FOR2240, EU COST CA18116 for their funding and support.

Conflicts of Interest: The authors declare no conflict of interest.

\section{References}

1. Cursiefen, C.; Schlotzer-Schrehardt, U.; Kuchle, M.; Sorokin, L.; Breiteneder-Geleff, S.; Alitalo, K.; Jackson, D. Lymphatic vessels in vascularized human corneas: Immunohistochemical investigation using LYVE-1 and podoplanin. Invest. Ophthalmol Vis. Sci 2002, 43, 2127-2135. [PubMed]

2. Chen, L. Ocular lymphatics: State-of-the-art review. Lymphology 2009, 42, 66-76. [PubMed]

3. Dietrich, T.; Bock, F.; Yuen, D.; Hos, D.; Bachmann, B.O.; Zahn, G.; Wiegand, S.; Chen, L.; Cursiefen, C. Cutting edge: Lymphatic vessels, not blood vessels, primarily mediate immune rejections after transplantation. J. Immunol 2010, 184, 535-539. [CrossRef] [PubMed]

4. Cursiefen, C.; Chen, L.; Dana, M.R.; Streilein, J.W. Corneal lymphangiogenesis: Evidence, mechanisms, and implications for corneal transplant immunology. Cornea 2003, 22, 273-281. [CrossRef]

5. Streilein, J.W. Ocular immune privilege: Therapeutic opportunities from an experiment of nature. Nat. Rev. Immunol 2003, 3, 879-889. [CrossRef]

6. Oh, S.J.; Jeltsch, M.M.; Birkenhager, R.; McCarthy, J.E.; Weich, H.A.; Christ, B.; Alitalo, K.; Wilting, J. VEGF and VEGF-C: Specific induction of angiogenesis and lymphangiogenesis in the differentiated avian chorioallantoic membrane. Dev. Biol 1997, 188, 96-109. [CrossRef]

7. Otrock, Z.K.; Makarem, J.A.; Shamseddine, A.I. Vascular endothelial growth factor family of ligands and receptors: Review. Blood Cells Mol. Dis 2007, 38, 258-268. [CrossRef]

8. Vlahakis, N.E.; Young, B.A.; Atakilit, A.; Sheppard, D. The lymphangiogenic vascular endothelial growth factors VEGF-C and -D are ligands for the integrin alpha9beta1. J. Biol Chem 2005, 280, 4544-4552. [CrossRef]

9. Heldin, C.H.; Westermark, B. Mechanism of action and in vivo role of platelet-derived growth factor. Physiol Rev. 1999, 79, 1283-1316. [CrossRef]

10. Bussolino, F.; Albini, A.; Camussi, G.; Presta, M.; Viglietto, G.; Ziche, M.; Persico, G. Role of soluble mediators in angiogenesis. Eur J. Cancer 1996, 32A, 2401-2412. [CrossRef]

11. Berdugo, M.; Andrieu-Soler, C.; Doat, M.; Courtois, Y.; BenEzra, D.; Behar-Cohen, F. Downregulation of IRS-1 expression causes inhibition of corneal angiogenesis. Invest. Ophthalmol Vis. Sci 2005, 46, 4072-4078. [CrossRef] [PubMed]

12. Achen, M.G.; Jeltsch, M.; Kukk, E.; Makinen, T.; Vitali, A.; Wilks, A.F.; Alitalo, K.; Stacker, S.A. Vascular endothelial growth factor D (VEGF-D) is a ligand for the tyrosine kinases VEGF receptor 2 (Flk1) and VEGF receptor 3 (Flt4). Proc. Natl. Acad. Sci. USA 1998, 95, 548-553. [CrossRef] [PubMed]

13. Bock, F.; Onderka, J.; Dietrich, T.; Bachmann, B.; Kruse, F.E.; Paschke, M.; Zahn, G.; Cursiefen, C. Bevacizumab as a potent inhibitor of inflammatory corneal angiogenesis and lymphangiogenesis. Invest. Ophthalmol Vis. Sci 2007, 48, 2545-2552. [CrossRef] [PubMed]

14. Cursiefen, C.; Chen, L.; Borges, L.P.; Jackson, D.; Cao, J.; Radziejewski, C.; D’Amore, P.A.; Dana, M.R.; Wiegand, S.J.; Streilein, J.W. VEGF-A stimulates lymphangiogenesis and hemangiogenesis in inflammatory neovascularization via macrophage recruitment. J. Clin. Invest. 2004, 113, 1040-1050. [CrossRef] [PubMed]

15. Maruyama, K.; Li, M.; Cursiefen, C.; Jackson, D.G.; Keino, H.; Tomita, M.; Van Rooijen, N.; Takenaka, H.; D'Amore, P.A.; Stein-Streilein, J.; et al. Inflammation-induced lymphangiogenesis in the cornea arises from CD11b-positive macrophages. J. Clin. Invest. 2005, 115, 2363-2372. [CrossRef] [PubMed]

16. Pepper, M.S.; Wasi, S.; Ferrara, N.; Orci, L.; Montesano, R. In vitro angiogenic and proteolytic properties of bovine lymphatic endothelial cells. Exp Cell Res 1994, 210, 298-305. [CrossRef]

17. Jitariu, A.A.; Cimpean, A.M.; Kundnani, N.R.; Raica, M. Platelet-derived growth factors induced lymphangiogenesis: Evidence, unanswered questions and upcoming challenges. Arch. Med. Sci 2015, 11, 57-66. [CrossRef] 
18. Tammela, T.; Saaristo, A.; Lohela, M.; Morisada, T.; Tornberg, J.; Norrmen, C.; Oike, Y.; Pajusola, K.; Thurston, G.; Suda, T.; et al. Angiopoietin-1 promotes lymphatic sprouting and hyperplasia. Blood 2005, 105, 4642-4648. [CrossRef]

19. Yuen, D.; Grimaldo, S.; Sessa, R.; Ecoiffier, T.; Truong, T.; Huang, E.; Bernas, M.; Daley, S.; Witte, M.; Chen, L. Role of angiopoietin-2 in corneal lymphangiogenesis. Invest. Ophthalmol Vis. Sci. 2014, 55, 3320-3327. [CrossRef]

20. Kajiya, K.; Hirakawa, S.; Ma, B.; Drinnenberg, I.; Detmar, M. Hepatocyte growth factor promotes lymphatic vessel formation and function. EMBO J. 2005, 24, 2885-2895. [CrossRef]

21. Alitalo, K.; Tammela, T.; Petrova, T.V. Lymphangiogenesis in development and human disease. Nature 2005, 438, 946-953. [CrossRef] [PubMed]

22. Jiang, X.; Nicolls, M.R.; Tian, W.; Rockson, S.G. Lymphatic Dysfunction, Leukotrienes, and Lymphedema. Annu Rev. Physiol 2018, 80, 49-70. [CrossRef] [PubMed]

23. Sprague, A.H.; Khalil, R.A. Inflammatory cytokines in vascular dysfunction and vascular disease. Biochem Pharmacol 2009, 78, 539-552. [CrossRef] [PubMed]

24. Tecchio, C.; Micheletti, A.; Cassatella, M.A. Neutrophil-derived cytokines: Facts beyond expression. Front. Immunol 2014, 5, 508. [CrossRef]

25. Peppicelli, S.; Bianchini, F.; Calorini, L. Inflammatory cytokines induce vascular endothelial growth factor-C expression in melanoma-associated macrophages and stimulate melanoma lymph node metastasis. Oncol Lett 2014, 8, 1133-1138. [CrossRef]

26. Savetsky, I.L.; Ghanta, S.; Gardenier, J.C.; Torrisi, J.S.; Garcia Nores, G.D.; Hespe, G.E.; Nitti, M.D.; Kataru, R.P.; Mehrara, B.J. Th2 cytokines inhibit lymphangiogenesis. PLoS ONE 2015, 10, e0126908. [CrossRef]

27. Shin, K.; Kataru, R.P.; Park, H.J.; Kwon, B.I.; Kim, T.W.; Hong, Y.K.; Lee, S.H. TH2 cells and their cytokines regulate formation and function of lymphatic vessels. Nat. Commun 2015, 6, 6196. [CrossRef]

28. Ambati, B.K.; Nozaki, M.; Singh, N.; Takeda, A.; Jani, P.D.; Suthar, T.; Albuquerque, R.J.; Richter, E.; Sakurai, E.; Newcomb, M.T.; et al. Corneal avascularity is due to soluble VEGF receptor-1. Nature 2006, 443, 993-997. [CrossRef]

29. Azar, D.T. Corneal angiogenic privilege: Angiogenic and antiangiogenic factors in corneal avascularity, vasculogenesis, and wound healing (an American Ophthalmological Society thesis). Trans. Am. Ophthalmol Soc. 2006, 104, 264-302.

30. Cursiefen, C. Immune privilege and angiogenic privilege of the cornea. Chem Immunol Allergy 2007, 92, 50-57. [CrossRef]

31. Lawler, J. The functions of thrombospondin-1 and-2. Curr Opin Cell Biol 2000, 12, 634-640. [CrossRef]

32. O’Reilly, M.S.; Boehm, T.; Shing, Y.; Fukai, N.; Vasios, G.; Lane, W.S.; Flynn, E.; Birkhead, J.R.; Olsen, B.R.; Folkman, J. Endostatin: An endogenous inhibitor of angiogenesis and tumor growth. Cell 1997, 88, 277-285. [CrossRef]

33. Chen, S.; Mienaltowski, M.J.; Birk, D.E. Regulation of corneal stroma extracellular matrix assembly. Exp. Eye Res. 2015, 133, 69-80. [CrossRef]

34. Ishizaki, M.; Shimoda, M.; Wakamatsu, K.; Ogro, T.; Yamanaka, N.; Kao, C.W.; Kao, W.W. Stromal fibroblasts are associated with collagen IV in scar tissues of alkali-burned and lacerated corneas. Curr Eye Res. 1997, 16, 339-348. [CrossRef]

35. Frikeche, J.; Maiti, G.; Chakravarti, S. Small leucine-rich repeat proteoglycans in corneal inflammation and wound healing. Exp. Eye Res. 2016, 151, 142-149. [CrossRef]

36. Amjadi, S.; Mai, K.; McCluskey, P.; Wakefield, D. The role of lumican in ocular disease. ISRN Ophthalmol 2013, 2013, 632302. [CrossRef]

37. Faye, C.; Moreau, C.; Chautard, E.; Jetne, R.; Fukai, N.; Ruggiero, F.; Humphries, M.J.; Olsen, B.R.; Ricard-Blum, S. Molecular interplay between endostatin, integrins, and heparan sulfate. J. Biol Chem 2009, 284, 22029-22040. [CrossRef]

38. Su, J.; Stenbjorn, R.S.; Gorse, K.; Su, K.; Hauser, K.F.; Ricard-Blum, S.; Pihlajaniemi, T.; Fox, M.A. Target-derived matricryptins organize cerebellar synapse formation through alpha3beta1 integrins. Cell Rep. 2012, 2, $223-230$. [CrossRef]

39. Walia, A.; Yang, J.F.; Huang, Y.H.; Rosenblatt, M.I.; Chang, J.H.; Azar, D.T. Endostatin's emerging roles in angiogenesis, lymphangiogenesis, disease, and clinical applications. Biochim Biophys Acta 2015, 1850, 2422-2438. [CrossRef] 
40. Bix, G.; Iozzo, R.V. Matrix revolutions: "tails" of basement-membrane components with angiostatic functions. Trends Cell Biol 2005, 15, 52-60. [CrossRef]

41. Mundel, T.M.; Kalluri, R. Type IV collagen-derived angiogenesis inhibitors. Microvasc Res. 2007, 74, 85-89. [CrossRef] [PubMed]

42. Tarui, T.; Miles, L.A.; Takada, Y. Specific interaction of angiostatin with integrin alpha(v)beta(3) in endothelial cells. J. Biol Chem 2001, 276, 39562-39568. [CrossRef] [PubMed]

43. Troyanovsky, B.; Levchenko, T.; Mansson, G.; Matvijenko, O.; Holmgren, L. Angiomotin: An angiostatin binding protein that regulates endothelial cell migration and tube formation. J. Cell Biol 2001, 152, 1247-1254. [CrossRef] [PubMed]

44. Cursiefen, C.; Masli, S.; Ng, T.F.; Dana, M.R.; Bornstein, P.; Lawler, J.; Streilein, J.W. Roles of thrombospondin-1 and -2 in regulating corneal and iris angiogenesis. Invest. Ophthalmol Vis. Sci 2004, 45, 1117-1124. [CrossRef]

45. Lawler, J. Thrombospondin-1 as an endogenous inhibitor of angiogenesis and tumor growth. J. Cell Mol. Med. 2002, 6, 1-12. [CrossRef]

46. Kendall, R.L.; Thomas, K.A. Inhibition of vascular endothelial cell growth factor activity by an endogenously encoded soluble receptor. Proc. Natl. Acad. Sci. USA 1993, 90, 10705-10709. [CrossRef]

47. Albuquerque, R.J.; Hayashi, T.; Cho, W.G.; Kleinman, M.E.; Dridi, S.; Takeda, A.; Baffi, J.Z.; Yamada, K.; Kaneko, H.; Green, M.G.; et al. Alternatively spliced vascular endothelial growth factor receptor-2 is an essential endogenous inhibitor of lymphatic vessel growth. Nat. Med. 2009, 15, 1023-1030. [CrossRef]

48. Singh, N.; Tiem, M.; Watkins, R.; Cho, Y.K.; Wang, Y.; Olsen, T.; Uehara, H.; Mamalis, C.; Luo, L.; Oakey, Z.; et al. Soluble vascular endothelial growth factor receptor 3 is essential for corneal alymphaticity. Blood 2013, 121, 4242-4249. [CrossRef]

49. Makinen, T.; Jussila, L.; Veikkola, T.; Karpanen, T.; Kettunen, M.I.; Pulkkanen, K.J.; Kauppinen, R.; Jackson, D.G.; Kubo, H.; Nishikawa, S.; et al. Inhibition of lymphangiogenesis with resulting lymphedema in transgenic mice expressing soluble VEGF receptor-3. Nat. Med. 2001, 7, 199-205. [CrossRef]

50. Cursiefen, C.; Chen, L.; Saint-Geniez, M.; Hamrah, P.; Jin, Y.; Rashid, S.; Pytowski, B.; Persaud, K.; Wu, Y.; Streilein, J.W.; et al. Nonvascular VEGF receptor 3 expression by corneal epithelium maintains avascularity and vision. Proc. Natl. Acad. Sci. USA 2006, 103, 11405-11410. [CrossRef]

51. Emami-Naeini, P.; Dohlman, T.H.; Omoto, M.; Hattori, T.; Chen, Y.; Lee, H.S.; Chauhan, S.K.; Dana, R. Soluble vascular endothelial growth factor receptor-3 suppresses allosensitization and promotes corneal allograft survival. Graefes Arch. Clin. Exp. Ophthalmol 2014, 252, 1755-1762. [CrossRef] [PubMed]

52. Cursiefen, C.; Cao, J.; Chen, L.; Liu, Y.; Maruyama, K.; Jackson, D.; Kruse, F.E.; Wiegand, S.J.; Dana, M.R.; Streilein, J.W. Inhibition of hemangiogenesis and lymphangiogenesis after normal-risk corneal transplantation by neutralizing VEGF promotes graft survival. Invest. Ophthalmol Vis. Sci 2004, 45, 2666-2673. [CrossRef] [PubMed]

53. Hos, D.; Regenfuss, B.; Bock, F.; Onderka, J.; Cursiefen, C. Blockade of insulin receptor substrate-1 inhibits corneal lymphangiogenesis. Invest. Ophthalmol Vis. Sci 2011, 52, 5778-5785. [CrossRef]

54. Dohlman, T.H.; Omoto, M.; Hua, J.; Stevenson, W.; Lee, S.M.; Chauhan, S.K.; Dana, R. VEGF-trap aflibercept significantly improves long-term graft survival in high-risk corneal transplantation. Transplantation 2015, 99, 678-686. [CrossRef] [PubMed]

55. Dastjerdi, M.H.; Saban, D.R.; Okanobo, A.; Nallasamy, N.; Sadrai, Z.; Chauhan, S.K.; Hajrasouliha, A.R.; Dana, R. Effects of topical and subconjunctival bevacizumab in high-risk corneal transplant survival. Invest. Ophthalmol Vis. Sci 2010, 51, 2411-2417. [CrossRef] [PubMed]

56. Gupta, A.A.; Mammo, D.A.; Page, M.A. Intrastromal bevacizumab in the management of corneal neovascularization: A retrospective review. Graefes Arch. Clin. Exp. Ophthalmol 2019. [CrossRef]

57. Sarah, B.; Ibtissam, H.; Mohammed, B.; Hasna, S.; Abdeljalil, M. Intrastromal Injection of Bevacizumab in the Management of Corneal Neovascularization: About 25 Eyes. J. Ophthalmol 2016, 2016, 6084270. [CrossRef] [PubMed]

58. Yeung, S.N.; Lichtinger, A.; Kim, P.; Amiran, M.D.; Slomovic, A.R. Combined use of subconjunctival and intracorneal bevacizumab injection for corneal neovascularization. Cornea 2011, 30, 1110-1114. [CrossRef]

59. Bhatti, N.; Qidwai, U.; Hussain, M.; Kazi, A. Efficacy of topical bevacizumab in high-risk corneal transplant survival. Pak. J. Med. Sci 2013, 29, 519-522. [CrossRef] 
60. Dekaris, I.; Gabric, N.; Draca, N.; Pauk-Gulic, M.; Milicic, N. Three-year corneal graft survival rate in high-risk cases treated with subconjunctival and topical bevacizumab. Graefes Arch. Clin. Exp. Ophthalmol 2015, 253, 287-294. [CrossRef]

61. Koenig, Y.; Bock, F.; Horn, F.; Kruse, F.; Straub, K.; Cursiefen, C. Short- and long-term safety profile and efficacy of topical bevacizumab (Avastin) eye drops against corneal neovascularization. Graefes Arch. Clin. Exp. Ophthalmol 2009, 247, 1375-1382. [CrossRef] [PubMed]

62. Bhatti, N.; Qidwai, U.; Hussain, M.; Kazi, A. Efficacy of sub-conjunctival and topical bevacizumab in high-risk corneal transplant survival. J. Pak. Med. Assoc. 2013, 63, 1256-1259. [PubMed]

63. Hos, D.; Le, V.N.H.; Hellmich, M.; Siebelmann, S.; Roters, S.; Bachmann, B.O.; Cursiefen, C. Risk of Corneal Graft Rejection After High-risk Keratoplasty Following Fine-needle Vessel Coagulation of Corneal Neovascularization Combined With Bevacizumab: A Pilot Study. Transplant. Direct 2019, 5, e452. [CrossRef] [PubMed]

64. White, M.F. The IRS-signaling system: A network of docking proteins that mediate insulin and cytokine action. Recent Prog Horm Res. 1998, 53, 119-138.

65. Cursiefen, C.; Viaud, E.; Bock, F.; Geudelin, B.; Ferry, A.; Kadlecova, P.; Levy, M.; Al Mahmood, S.; Colin, S.; Thorin, E.; et al. Aganirsen antisense oligonucleotide eye drops inhibit keratitis-induced corneal neovascularization and reduce need for transplantation: The I-CAN study. Ophthalmology 2014, 121, 1683-1692. [CrossRef]

66. Niederkorn, J.Y. Immune mechanisms of corneal allograft rejection. Curr Eye Res. 2007, 32, $1005-1016$. [CrossRef]

67. Hajrasouliha, A.R.; Funaki, T.; Sadrai, Z.; Hattori, T.; Chauhan, S.K.; Dana, R. Vascular endothelial growth factor-C promotes alloimmunity by amplifying antigen-presenting cell maturation and lymphangiogenesis. Invest. Ophthalmol Vis. Sci 2012, 53, 1244-1250. [CrossRef]

68. Acton, S.E.; Astarita, J.L.; Malhotra, D.; Lukacs-Kornek, V.; Franz, B.; Hess, P.R.; Jakus, Z.; Kuligowski, M.; Fletcher, A.L.; Elpek, K.G.; et al. Podoplanin-rich stromal networks induce dendritic cell motility via activation of the C-type lectin receptor CLEC-2. Immunity 2012, 37, 276-289. [CrossRef]

69. Colonna, M.; Samaridis, J.; Angman, L. Molecular characterization of two novel C-type lectin-like receptors, one of which is selectively expressed in human dendritic cells. Eur J. Immunol 2000, 30, 697-704. [CrossRef]

70. Kerjaschki, D.; Regele, H.M.; Moosberger, I.; Nagy-Bojarski, K.; Watschinger, B.; Soleiman, A.; Birner, P.; Krieger, S.; Hovorka, A.; Silberhumer, G.; et al. Lymphatic neoangiogenesis in human kidney transplants is associated with immunologically active lymphocytic infiltrates. J. Am. Soc. Nephrol 2004, 15, 603-612. [CrossRef]

71. Turley, S.J.; Fletcher, A.L.; Elpek, K.G. The stromal and haematopoietic antigen-presenting cells that reside in secondary lymphoid organs. Nat. Rev. Immunol 2010, 10, 813-825. [CrossRef] [PubMed]

72. Maruyama, Y.; Maruyama, K.; Kato, Y.; Kajiya, K.; Moritoh, S.; Yamamoto, K.; Matsumoto, Y.; Sawane, M.; Kerjaschki, D.; Nakazawa, T.; et al. The effect of podoplanin inhibition on lymphangiogenesis under pathological conditions. Invest. Ophthalmol Vis. Sci 2014, 55, 4813-4822. [CrossRef] [PubMed]

73. Garmy-Susini, B.; Varner, J.A. Roles of integrins in tumor angiogenesis and lymphangiogenesis. Lymphat Res. Biol 2008, 6, 155-163. [CrossRef] [PubMed]

74. Mishima, K.; Watabe, T.; Saito, A.; Yoshimatsu, Y.; Imaizumi, N.; Masui, S.; Hirashima, M.; Morisada, T.; Oike, Y.; Araie, M.; et al. Prox1 induces lymphatic endothelial differentiation via integrin alpha9 and other signaling cascades. Mol. Biol Cell 2007, 18, 1421-1429. [CrossRef]

75. Kang, G.J.; Truong, T.; Huang, E.; Su, V.; Ge, S.; Chen, L. Integrin Alpha 9 Blockade Suppresses Lymphatic Valve Formation and Promotes Transplant Survival. Invest. Ophthalmol Vis. Sci 2016, 57, 5935-5939. [CrossRef]

76. Garmy-Susini, B.; Makale, M.; Fuster, M.; Varner, J.A. Methods to study lymphatic vessel integrins. Methods Enzymol 2007, 426, 415-438. [CrossRef]

77. Nasarre, P.; Gemmill, R.M.; Drabkin, H.A. The emerging role of class-3 semaphorins and their neuropilin receptors in oncology. Onco Targets Ther 2014, 7, 1663-1687. [CrossRef]

78. Suto, F.; Ito, K.; Uemura, M.; Shimizu, M.; Shinkawa, Y.; Sanbo, M.; Shinoda, T.; Tsuboi, M.; Takashima, S.; Yagi, T.; et al. Plexin-a4 mediates axon-repulsive activities of both secreted and transmembrane semaphorins and plays roles in nerve fiber guidance. J. Neurosci 2005, 25, 3628-3637. [CrossRef] 
79. Takahashi, T.; Fournier, A.; Nakamura, F.; Wang, L.H.; Murakami, Y.; Kalb, R.G.; Fujisawa, H.; Strittmatter, S.M. Plexin-neuropilin-1 complexes form functional semaphorin-3A receptors. Cell 1999, 99, 59-69. [CrossRef]

80. Buehler, A.; Sitaras, N.; Favret, S.; Bucher, F.; Berger, S.; Pielen, A.; Joyal, J.S.; Juan, A.M.; Martin, G.; Schlunck, G.; et al. Semaphorin 3F forms an anti-angiogenic barrier in outer retina. FEBS Lett 2013, 587, 1650-1655. [CrossRef]

81. Sun, Y.; Liegl, R.; Gong, Y.; Buhler, A.; Cakir, B.; Meng, S.S.; Burnim, S.B.; Liu, C.H.; Reuer, T.; Zhang, P.; et al. Sema3f Protects Against Subretinal Neovascularization In Vivo. EBioMedicine 2017, 18, 281-287. [CrossRef] [PubMed]

82. Reuer, T.; Schneider, A.C.; Cakir, B.; Buhler, A.D.; Walz, J.M.; Lapp, T.; Lange, C.; Agostini, H.; Schlunck, G.; Cursiefen, C.; et al. Semaphorin 3F Modulates Corneal Lymphangiogenesis and Promotes Corneal Graft Survival. Invest. Ophthalmol Vis. Sci 2018, 59, 5277-5284. [CrossRef] [PubMed]

83. Cursiefen, C.; Maruyama, K.; Bock, F.; Saban, D.; Sadrai, Z.; Lawler, J.; Dana, R.; Masli, S. Thrombospondin 1 inhibits inflammatory lymphangiogenesis by CD36 ligation on monocytes. J. Exp. Med. 2011, 208, 1083-1092. [CrossRef] [PubMed]

84. Heishi, T.; Hosaka, T.; Suzuki, Y.; Miyashita, H.; Oike, Y.; Takahashi, T.; Nakamura, T.; Arioka, S.; Mitsuda, Y.; Takakura, T.; et al. Endogenous angiogenesis inhibitor vasohibin1 exhibits broad-spectrum antilymphangiogenic activity and suppresses lymph node metastasis. Am. J. Pathol 2010, 176, 1950-1958. [CrossRef]

85. Xu, Y.; Yuan, L.; Mak, J.; Pardanaud, L.; Caunt, M.; Kasman, I.; Larrivee, B.; Del Toro, R.; Suchting, S.; Medvinsky, A.; et al. Neuropilin-2 mediates VEGF-C-induced lymphatic sprouting together with VEGFR3. J. Cell Biol 2010, 188, 115-130. [CrossRef]

86. Watanabe, K.; Hasegawa, Y.; Yamashita, H.; Shimizu, K.; Ding, Y.; Abe, M.; Ohta, H.; Imagawa, K.; Hojo, K.; Maki, H.; et al. Vasohibin as an endothelium-derived negative feedback regulator of angiogenesis. J. Clin. Invest. 2004, 114, 898-907. [CrossRef]

87. Tang, X.L.; Sun, J.F.; Wang, X.Y.; Du, L.L.; Liu, P. Blocking neuropilin-2 enhances corneal allograft survival by selectively inhibiting lymphangiogenesis on vascularized beds. Mol. Vis. 2010, 16, 2354-2361.

88. Egeblad, M.; Werb, Z. New functions for the matrix metalloproteinases in cancer progression. Nat. Rev. Cancer 2002, 2, 161-174. [CrossRef]

89. McCawley, L.J.; Matrisian, L.M. Matrix metalloproteinases: Multifunctional contributors to tumor progression. Mol. Med. Today 2000, 6, 149-156. [CrossRef]

90. Barbolina, M.V.; Stack, M.S. Membrane type 1-matrix metalloproteinase: Substrate diversity in pericellular proteolysis. Semin Cell Dev. Biol 2008, 19, 24-33. [CrossRef]

91. Han, K.Y.; Dugas-Ford, J.; Lee, H.; Chang, J.H.; Azar, D.T. MMP14 Cleavage of VEGFR1 in the Cornea Leads to a VEGF-Trap Antiangiogenic Effect. Invest. Ophthalmol Vis. Sci 2015, 56, 5450-5456. [CrossRef] [PubMed]

92. Wong, H.L.; Cao, R.; Jin, G.; Chan, K.M.; Cao, Y.; Zhou, Z. When MT1-MMP meets ADAMs. Cell Cycle 2012, 11, 2793-2798. [CrossRef] [PubMed]

93. Zhou, Z.; Apte, S.S.; Soininen, R.; Cao, R.; Baaklini, G.Y.; Rauser, R.W.; Wang, J.; Cao, Y.; Tryggvason, K. Impaired endochondral ossification and angiogenesis in mice deficient in membrane-type matrix metalloproteinase I. Proc. Natl. Acad. Sci. USA 2000, 97, 4052-4057. [CrossRef] [PubMed]

94. Wong, H.L.; Jin, G.; Cao, R.; Zhang, S.; Cao, Y.; Zhou, Z. MT1-MMP sheds LYVE-1 on lymphatic endothelial cells and suppresses VEGF-C production to inhibit lymphangiogenesis. Nat. Commun 2016, 7, 10824. [CrossRef]

95. Du, H.T.; Du, L.L.; Tang, X.L.; Ge, H.Y.; Liu, P. Blockade of MMP-2 and MMP-9 inhibits corneal lymphangiogenesis. Graefes Arch. Clin. Exp. Ophthalmol 2017, 255, 1573-1579. [CrossRef]

96. Bock, F.; Onderka, J.; Braun, G.; Schneider, A.C.; Hos, D.; Bi, Y.; Bachmann, B.O.; Cursiefen, C. Identification of Novel Endogenous Anti(lymph)angiogenic Factors in the Aqueous Humor. Invest. Ophthalmol Vis. Sci 2016, 57, 6554-6560. [CrossRef]

97. Nacher, J.C. Community structure of non-coding RNA interaction network. J. Integr Bioinform 2013, 10, 217. [CrossRef]

98. Bartel, D.P. MicroRNAs: Genomics, biogenesis, mechanism, and function. Cell 2004, 116, 281-297. [CrossRef]

99. Filipowicz, W.; Bhattacharyya, S.N.; Sonenberg, N. Mechanisms of post-transcriptional regulation by microRNAs: Are the answers in sight? Nat. Rev. Genet. 2008, 9, 102-114. [CrossRef] 
100. Khan, A.; Nasr, P.; El-Charabaty, E.; El-Sayegh, S. An Insight Into the Immunologic Events and Risk Assessment in Renal Transplantation. J. Clin. Med. Res. 2016, 8, 367-372. [CrossRef]

101. Oghumu, S.; Bracewell, A.; Nori, U.; Maclean, K.H.; Balada-Lasat, J.M.; Brodsky, S.; Pelletier, R.; Henry, M.; Satoskar, A.R.; Nadasdy, T.; et al. Acute pyelonephritis in renal allografts: A new role for microRNAs? Transplantation 2014, 97, 559-568. [CrossRef] [PubMed]

102. Lu, X.; Wu, J.; Ma, M.; Wu, X.; Wen, J.; Yu, J. An integrated deep sequencing analysis of microRNAs in transplanted corneas. Mol. Immunol 2018, 101, 429-439. [CrossRef]

103. Wang, T.; Li, F.; Geng, W.; Ruan, Q.; Shi, W. MicroRNA-122 ameliorates corneal allograft rejection through the downregulation of its target CPEB1. Cell Death Discov 2017, 3, 17021. [CrossRef] [PubMed]

104. Grimaldo, S.; Yuen, D.; Theis, J.; Ng, M.; Ecoiffier, T.; Chen, L. MicroRNA-184 Regulates Corneal Lymphangiogenesis. Invest. Ophthalmol Vis. Sci 2015, 56, 7209-7213. [CrossRef]

105. Hong, Y.K.; Detmar, M. Prox1, master regulator of the lymphatic vasculature phenotype. Cell Tissue Res. 2003, 314, 85-92. [CrossRef]

106. Hong, Y.K.; Harvey, N.; Noh, Y.H.; Schacht, V.; Hirakawa, S.; Detmar, M.; Oliver, G. Prox1 is a master control gene in the program specifying lymphatic endothelial cell fate. Dev. Dyn 2002, 225, 351-357. [CrossRef]

107. Wigle, J.T.; Harvey, N.; Detmar, M.; Lagutina, I.; Grosveld, G.; Gunn, M.D.; Jackson, D.G.; Oliver, G. An essential role for Prox1 in the induction of the lymphatic endothelial cell phenotype. EMBO J. 2002, 21, 1505-1513. [CrossRef]

108. Kazenwadel, J.; Michael, M.Z.; Harvey, N.L. Prox1 expression is negatively regulated by miR-181 in endothelial cells. Blood 2010, 116, 2395-2401. [CrossRef]

109. Pedrioli, D.M.; Karpanen, T.; Dabouras, V.; Jurisic, G.; van de Hoek, G.; Shin, J.W.; Marino, D.; Kalin, R.E.; Leidel, S.; Cinelli, P.; et al. miR-31 functions as a negative regulator of lymphatic vascular lineage-specific differentiation in vitro and vascular development in vivo. Mol. Cell Biol 2010, 30, 3620-3634. [CrossRef]

110. Seo, M.; Choi, J.S.; Rho, C.R.; Joo, C.K.; Lee, S.K. MicroRNA miR-466 inhibits Lymphangiogenesis by targeting prospero-related homeobox 1 in the alkali burn corneal injury model. J. Biomed. Sci 2015, 22, 3. [CrossRef]

111. Dumont, D.J.; Jussila, L.; Taipale, J.; Lymboussaki, A.; Mustonen, T.; Pajusola, K.; Breitman, M.; Alitalo, K. Cardiovascular failure in mouse embryos deficient in VEGF receptor-3. Science 1998, 282, 946-949. [CrossRef] [PubMed]

112. Tammela, T.; Alitalo, K. Lymphangiogenesis: Molecular mechanisms and future promise. Cell 2010, 140, 460-476. [CrossRef] [PubMed]

113. Flister, M.J.; Wilber, A.; Hall, K.L.; Iwata, C.; Miyazono, K.; Nisato, R.E.; Pepper, M.S.; Zawieja, D.C.; Ran, S. Inflammation induces lymphangiogenesis through up-regulation of VEGFR-3 mediated by NF-kappaB and Prox1. Blood 2010, 115, 418-429. [CrossRef] [PubMed]

114. Jones, D.; Li, Y.; He, Y.; Xu, Z.; Chen, H.; Min, W. Mirtron microRNA-1236 inhibits VEGFR-3 signaling during inflammatory lymphangiogenesis. Arterioscler Thromb Vasc Biol 2012, 32, 633-642. [CrossRef]

115. Chakraborty, S.; Zawieja, D.C.; Davis, M.J.; Muthuchamy, M. MicroRNA signature of inflamed lymphatic endothelium and role of miR-9 in lymphangiogenesis and inflammation. Am. J. Physiol Cell Physiol 2015, 309, C680-692. [CrossRef]

116. Kontarakis, Z.; Rossi, A.; Ramas, S.; Dellinger, M.T.; Stainier, D.Y.R. Mir-126 is a conserved modulator of lymphatic development. Dev. Biol 2018, 437, 120-130. [CrossRef]

117. Borza, C.M.; Pozzi, A. Discoidin domain receptors in disease. Matrix Biol 2014, 34, 185-192. [CrossRef]

118. Oh, S.; Seo, M.; Choi, J.S.; Joo, C.K.; Lee, S.K. MiR-199a/b-5p Inhibits Lymphangiogenesis by Targeting Discoidin Domain Receptor 1 in Corneal Injury. Mol. Cells 2018, 41, 93-102. [CrossRef]

119. Yamanaka, R.; Arao, T.; Yajima, N.; Tsuchiya, N.; Homma, J.; Tanaka, R.; Sano, M.; Oide, A.; Sekijima, M.; Nishio, K. Identification of expressed genes characterizing long-term survival in malignant glioma patients. Oncogene 2006, 25, 5994-6002. [CrossRef]

120. Shrivastava, A.; Radziejewski, C.; Campbell, E.; Kovac, L.; McGlynn, M.; Ryan, T.E.; Davis, S.; Goldfarb, M.P.; Glass, D.J.; Lemke, G.; et al. An orphan receptor tyrosine kinase family whose members serve as nonintegrin collagen receptors. Mol. Cell 1997, 1, 25-34. [CrossRef]

121. Vogel, W.; Gish, G.D.; Alves, F.; Pawson, T. The discoidin domain receptor tyrosine kinases are activated by collagen. Mol. Cell 1997, 1, 13-23. [CrossRef] 
122. Xiao, Q.; Jiang, Y.; Liu, Q.; Yue, J.; Liu, C.; Zhao, X.; Qiao, Y.; Ji, H.; Chen, J.; Ge, G. Minor Type IV Collagen alpha5 Chain Promotes Cancer Progression through Discoidin Domain Receptor-1. PLoS Genet. 2015, 11, e1005249. [CrossRef] [PubMed]

123. Amaral, P.P.; Mattick, J.S. Noncoding RNA in development. Mamm Genome 2008, 19, 454-492. [CrossRef] [PubMed]

124. Taft, R.J.; Pang, K.C.; Mercer, T.R.; Dinger, M.; Mattick, J.S. Non-coding RNAs: Regulators of disease. J. Pathol 2010, 220, 126-139. [CrossRef]

125. Wilusz, J.E.; Sunwoo, H.; Spector, D.L. Long noncoding RNAs: Functional surprises from the RNA world. Genes Dev. 2009, 23, 1494-1504. [CrossRef]

126. Evans, J.R.; Feng, F.Y.; Chinnaiyan, A.M. The bright side of dark matter: IncRNAs in cancer. J. Clin. Invest. 2016, 126, 2775-2782. [CrossRef]

127. Chen, W.; Yang, S.; Zhou, Z.; Zhao, X.; Zhong, J.; Reinach, P.S.; Yan, D. The Long Noncoding RNA Landscape of the Mouse Eye. Invest. Ophthalmol Vis. Sci 2017, 58, 6308-6317. [CrossRef]

128. Sun, B.; Ding, Y.; Jin, X.; Xu, S.; Zhang, H. Long non-coding RNA H19 promotes corneal neovascularization by targeting microRNA-29c. Biosci Rep. 2019, 39. [CrossRef]

129. Sun, Z.; Ou, C.; Ren, W.; Xie, X.; Li, X.; Li, G. Downregulation of long non-coding RNA ANRIL suppresses lymphangiogenesis and lymphatic metastasis in colorectal cancer. Oncotarget 2016, 7, 47536-47555. [CrossRef]

130. He, W.; Zhong, G.; Jiang, N.; Wang, B.; Fan, X.; Chen, C.; Chen, X.; Huang, J.; Lin, T. Long noncoding RNA BLACAT2 promotes bladder cancer-associated lymphangiogenesis and lymphatic metastasis. J. Clin. Invest. 2018, 128, 861-875. [CrossRef]

131. Rohan, R.M.; Fernandez, A.; Udagawa, T.; Yuan, J.; D'Amato, R.J. Genetic heterogeneity of angiogenesis in mice. FASEB J. 2000, 14, 871-876. [CrossRef] [PubMed]

132. Rogers, M.S.; Rohan, R.M.; Birsner, A.E.; D'Amato, R.J. Genetic loci that control vascular endothelial growth factor-induced angiogenesis. FASEB J. 2003, 17, 2112-2114. [CrossRef] [PubMed]

133. Rogers, M.S.; Rohan, R.M.; Birsner, A.E.; D'Amato, R.J. Genetic loci that control the angiogenic response to basic fibroblast growth factor. FASEB J. 2004, 18, 1050-1059. [CrossRef] [PubMed]

134. Regenfuss, B.; Onderka, J.; Bock, F.; Hos, D.; Maruyama, K.; Cursiefen, C. Genetic heterogeneity of lymphangiogenesis in different mouse strains. Am. J. Pathol 2010, 177, 501-510. [CrossRef]

135. Regenfuss, B.; Dreisow, M.L.; Hos, D.; Masli, S.; Bock, F.; Cursiefen, C. The Naive Murine Cornea as a Model System to Identify Novel Endogenous Regulators of Lymphangiogenesis: TRAIL and rtPA. Lymphat Res. Biol 2015, 13, 76-84. [CrossRef]

136. Bock, F.; Onderka, J.; Hos, D.; Horn, F.; Martus, P.; Cursiefen, C. Improved semiautomatic method for morphometry of angiogenesis and lymphangiogenesis in corneal flatmounts. Exp. Eye Res. 2008, 87, 462-470. [CrossRef]

137. Buttner, C.; Clahsen, T.; Regenfuss, B.; Dreisow, M.L.; Steiber, Z.; Bock, F.; Reis, A.; Cursiefen, C. Tyrosinase Is a Novel Endogenous Regulator of Developmental and Inflammatory Lymphangiogenesis. Am. J. Pathol 2019, 189, 440-448. [CrossRef]

(C) 2020 by the authors. Licensee MDPI, Basel, Switzerland. This article is an open access article distributed under the terms and conditions of the Creative Commons Attribution (CC BY) license (http://creativecommons.org/licenses/by/4.0/). 